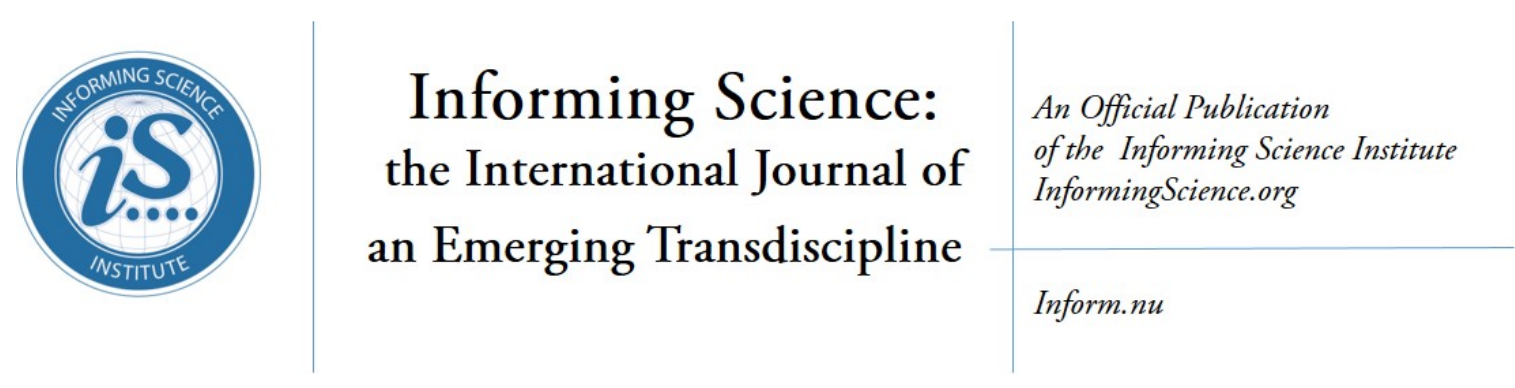

Volume 21, 2018

\title{
WHAT IS COLLABORATIVE, INTERDISCIPLINARY REASONING? THE HEART OF INTERDISCIPLINARY TEAM RESEARCH
}

Bethany K. Laursen Departments of Philosophy and Community $\quad \underline{\text { Laursen3@msu.edu }}$ Sustainability, Michigan State University, East Lansing, MI, USA

\section{ABSTRACT}

\begin{tabular}{|c|c|}
\hline Aim/Purpose & $\begin{array}{l}\text { Collaborative, interdisciplinary research is growing rapidly, but we still have } \\
\text { limited and fragmented understanding of what is arguably the heart of such } \\
\text { research-collaborative, interdisciplinary reasoning (CIR). }\end{array}$ \\
\hline Background & $\begin{array}{l}\text { This article integrates neo-Pragmatist theories of reasoning with insights } \\
\text { from literature on interdisciplinary research to develop a working definition } \\
\text { of collaborative, interdisciplinary reasoning. The article then applies this def- } \\
\text { inition to an empirical example to demonstrate its utility. }\end{array}$ \\
\hline Methodology & $\begin{array}{l}\text { The empirical example is an excerpt from a Toolbox workshop transcript. } \\
\text { The article reconstructs a cogent, inductive, interdisciplinary argument from } \\
\text { the excerpt to show how CIR can proceed in an actual team. }\end{array}$ \\
\hline Contribution & $\begin{array}{l}\text { The study contributes operational definitions of 'reasoning together' and } \\
\text { 'collaborative, interdisciplinary reasoning' to existing literature. It also } \\
\text { demonstrates empirical methods for operationalizing these definitions, with } \\
\text { the argument reconstruction providing a brief case study in how teams rea- } \\
\text { son together. }\end{array}$ \\
\hline
\end{tabular}

Findings $\quad 1$. Collaborative, interdisciplinary reasoning is the attempted integration of disciplinary contributions to exchange, evaluate, and assert claims that enable shared understanding and eventually action in a local context.

2. Pragma-dialectic argument reconstruction with conversation analysis is a method for observing such reasoning from a transcript.

3. The example team developed a strong inductive argument to integrate their disciplinary contributions about modeling.

This paper is one in a Special Series on Transdisciplinary Communication

Accepting Editor Gaetano Lotrecchiano | Received: September 29, 2017 | Revised: March 5, March 27, 2018 | Accepted: April 9, 2018.

Cite as: Laursen, B. K. (2018). What is collaborative, interdisciplinary reasoning? The heart of interdisciplinary team research. Informing Science: the International Journal of an Emerging Transdiscipline, 21, https://doi.org/10.28945/4010

(CC BY-NC 4.0) This article is licensed to you under a Creative Commons Attribution-NonCommercial 4.0 International License. When you copy and redistribute this paper in full or in part, you need to provide proper attribution to it to ensure that others can later locate this work (and to ensure that others do not accuse you of plagiarism). You may (and we encourage you to) adapt, remix, transform, and build upon the material for any non-commercial purposes. This license does not permit you to use this material for commercial purposes. 
Recommendations 1. Interdisciplinary work requires agreeing with teammates about what is for Practitioners assertible and why.

2. To assert something together legitimately requires making a cogent, integrated argument.

Recommendation for Researchers

1. An argument is the basic unit of analysis for interdisciplinary integration.

2. To assess the argument's cogency, it is helpful to reconstruct it using pragma-dialectic principles and conversation analysis tools.

3. To assess the argument's interdisciplinary integration and participant roles in the integration, it is helpful to graph the flow of words as a Sankey chart from participant-disciplines to the argument conclusion.

Future Research How does this definition of CIR relate to other interdisciplinary 'cognition' or 'learning' type theories? How can practitioners and theorists tell the difference between true intersubjectivity and superficial agreeableness in these dialogues? What makes an instance of CIR 'good' or 'bad'? How does collaborative, transdisciplinary reasoning differ from CIR, if at all?

Keywords argumentation, discourse, interdisciplinary, integration, intersubjectivity, transdisciplinary, Toolbox

\section{INTRODUCTION}

Collaborative, interdisciplinary research has grown dramatically in recent decades-both in prevalence as well as promise (Van Noorden, 2015). The National Academies recently reported that 90\% of scientific and engineering papers are now written by two or more authors (National Research Council, 2015, pp. 19-20), and many of these teams are interdisciplinary. In six domains, papers from 2005 referenced an average of 50\% more disciplines than papers from 1975 (Porter \& Rafols, 2009). The domains studied were (1) Biotechnology \& Applied Microbiology; (2) Engineering, Electrical \& Electronic; (3) Mathematics; (4) Medicine - Research \& Experimental; (5) Neurosciences; and (6) Physics - Atomic, Molecular \& Chemical). The trend towards interdisciplinary referencing practices-and by implication, interdisciplinary reasoning among author teams — has been especially marked since the mid-1980s (Lariviere \& Gingras, 2014).

Rapid expansion in collaborative, interdisciplinary research has been justified by both the epistemic and instrumental promises of this mode of research (National Research Council, 2005). Epistemically, the claim is that many problems - especially so-called "grand challenges" (De Grandis \& Efstathiou, 2016) or "wicked problems" (Brown, Harris, \& Russell, 2010; Rittel \& Webber, 1973)—cannot be understood by a single discipline. Rather, insights are claimed to be more relevant and more incisive when knowledge is integrated across disciplinary boundaries and interstices (National Research Council, 2005, pp. 16-17). Instrumentally, it often 'takes a village' to access the material, human, temporal, and technical resources needed to research such wicked problems (Hagstrom, 1964; Lewis, Ross, \& Holden 2012).

However advantageous, this form of research poses its own challenges, which have in turn sparked meta-research on collaborative, interdisciplinary processes - a literature to which this study contributes (e.g., Frodeman, Klein, \& Mitcham, 2010; Frodeman, Klein, \& Pacheco, 2017). Meta-research and lessons learned in practice have together produced a plethora of tools, frameworks, and constructs aimed to help us understand and address challenges inherent in cross-disciplinary teamwork (e.g., i2insights.org https://i2insights.org; National Institutes of Health National Cancer Institute, n.d.). 
What has been underrated in this meta-research and practice, however, is a clear understanding of what could be considered the most basic task of these research teams: collaborative, interdisciplinary reasoning. By reasoning, here, I mean making inferences from what we understand to what we don't understand (Scriven, 1976). Making inferences entails exploring implications of a claim, using some claims to justify or cast doubt on other claims. That is, reasoning assesses the "warranted assertibility" (Dewey, 1938, p. 9) of a claim by evaluating the implications of other, more well-established claims.

Broadly speaking, we engage in reasoning when someone wants to assert an idea and others want to assess the right to assert it. These desires create different kinds of discourse settings in which assertions are made and defended. Sometimes, what is asserted is an answer to a question. These discourse settings constitute inquiries. Research is a type of inquiry, and therefore reasoning is essential to it. Failing to understand this most essential activity results in limited progress in improving theory and practice of collaborative, interdisciplinary research.

This investigation contributes to filling the related conceptual gap by first proposing a definition of collaborative, interdisciplinary reasoning (CIR) based on the neo-Pragmatist reasoning and argumentation literature. Next follows an in-depth example of CIR so understood to illustrate that this form of reasoning in interdisciplinary teams is plausible. The paper concludes by reflecting on areas for future research. The tasks for future research include investigating situations in which reasoning goes poorly. This paper presents the ideal for CIR as a goal for which to aim. However, an ideal-by definition-is never fully realized. A full, ethical, and useful treatment of CIR must therefore consider non-ideal situations, providing conceptual frameworks and practical suggestions for engaging the real world. This paper provides an orienting direction for such future work. Future directions also include extension into collaborative, transdisciplinary reasoning. This paper focuses on interdisciplinary research as the integration rather than transcendence of disciplines, or as the incorporation of academic and non-academic stakeholders. This is because there is more literature on interdisciplinarity than transdisciplinarity and because interdisciplinarity remains a common goal in the research world. This paper aims, therefore, to contribute to interdisciplinary work directly and to transdisciplinary work by extension or transfer.

\section{COLLABORATIVE, INTERDISCIPLINARY REASONING DEFINED}

\section{REASONING TOGETHER DEFINED}

To reiterate, this article focuses upon reasoning that should occur among members of an interdisciplinary research project. Research here distinguishes inquiries that are planned and conducted systematically from those conducted more haphazardly. More specifically, Leedy and Ormrod (2005, p. 2), state, "Research is a systematic process of collecting, analyzing, and interpreting information (data) in order to increase our understanding of the phenomenon about which we are interested or concerned." Research, in other words, is a type of formal inquiry that seeks to increase understanding. In this conception, research occurs not only in academic settings but also in industrial and national laboratories, law enforcement offices, and non-profit organizations, to name a few places. Research projects might involve only one person, but the focus here is projects involving two or more collaborators.

CIR is a specific kind of the more general activity of reasoning together, requiring first an understanding of that more general concept. Communication is the vehicle for collaborative reasoning. J. Britt Holbrook (2013) helpfully identified three ways to understand communication, particularly as it applies to interdisciplinary research. One view is the Kuhn-MacIntyre thesis that reasoning across perspectives is not possible, because perspectives amount to incommensurable paradigms. Any collaborative reasoning that does occur requires one of the interlocutors to acquire "native fluency" in the relevant disciplinary languages, an accomplishment that is extremely difficult, rare, and in the end, not the integration of two paradigms. A second view, the Bataille-Lyotard thesis, holds that collabo- 
rative reasoning can proceed only by inventing a new language, built expressly for that discourse. Like the Kuhn-MacIntyre thesis, the Bataille-Lyotard thesis contends that different perspectives amount to incommensurable paradigms. However, unlike its Kuhn-MacIntyre counterpart, this thesis argues that commensurability is possible-but only through the invention of a custom-built language. A third major understanding of reasoning together is the Habermas-Klein thesis, which holds that collaborative reasoning is possible through integration of perspectives. While Holbrook's article does not acknowledge this, other work from the Habermas-Klein perspective discusses many possible paths to integration (Klein, 1996; 2014a, pp. 20-22; O’Rourke, Crowley, \& Gonnerman, 2016; Repko, Szostak, \& Buchberger, 2016). Some paths may involve the creation of a new language but others may integrate existing languages. Moreover, although the Habermas-Klein thesis emphasizes integration as the ideal, the thesis acknowledges that in reality some perspectives are incommensurable (whether for inherent or contextual reasons is up for debate in each case). Thus, while Holbrook may disagree with me, I believe the Habermas-Klein thesis accommodates both the Bataille-Lyotard and Kuhn-MacIntyre theses while also affirming what most of us tend to believe: that reasoning together does happen across different perspectives.

Therefore, for the purposes of this project the Habermas-Klein thesis is most appropriate. I emphasize one strand of this thesis with a conception of 'reasoning together' found in works by Jürgen Habermas (1985), Larry Wright (1995; 2001), and Christian Campolo (Campolo, 2005; Campolo \& Turner, 2002). This approach differs from perspectives of reasoning that have been more common in interdisciplinary literature, such as interdisciplinary learning (Augsburg \& Chitewere, 2013), thinking (Dreyfuss, 2011), and cognition (Derry, Schunn, \& Gernsbacher, 2013; Nikitina, 2005). The difference is that this neo-Pragmatist approach centers the social practice of giving reasons through discourse for the sake of coordinated action. It elevates the role of communication as a learning-fordoing tool while minimizing communication, learning, or doing treated separately: to neo-

Pragmatists, collaborative reasoning is cognitive and communicative and contextually practical all at once. With such a focus, new facets of interdisciplinary communication come into the spotlight. As discussed and exemplified below, these new facets include types of discourse, standards for assertion, argument structures (including premises and conclusions), and conversational moves. The article attempts to show these are valuable insights.

Habermas's (1985) theory of 'reasoning together' unfolds several types of argumentation that differ based on differing goals of discourse. Possible goals include finding truth ("theoretical discourse"), determining what is right action ("practical discourse"), establishing standards for value ("aesthetic criticism"), assessing authenticity of expression ("artistic critique"), and — as a meta-purposeclarifying the appropriate forms of the above discourses ("explicative discourse") (Habermas, 1985, p. 23). Regarding the last goal, we need such meta-discourse because we always risk reasoning about different types of things in inappropriate ways, e.g., confusing the way things are (finding truth) with the way things should be (determining what is right action, or establishing standards of value). Explicative discourse is especially important in interdisciplinary contexts as disciplines disagree about the appropriate way(s) to discuss many topics (Eigenbrode et al., 2007); indeed the interdisciplinary example analyzed below illustrates explicative discourse.

Habermas (1985) emphasizes that rational discourse toward the above goals always involves argumentation because rational discourse depends upon one's ability to evaluate reasons and inferences against shared ("transsubjective") standards of adequacy (p. 9). Such discourse can be understood as reasoning together, both because the claims and reasons are given in social contexts and because the standards by which those reasons are evaluated are socially constructed.

Intersubjective standards, as Wright and Campolo call them, are statements whose meaning is shared between interlocutors and is used to judge the acceptability of claims. For example, a common intersubjective standard in quantitative research is that statistical inferences must have a $p$ value below 0.05 to be considered credible (Wasserstein \& Lazar, 2016). Qualitative researchers, on the other hand, often require credible findings to be member checked (i.e., given approval by the respondents 
themselves) (Lincoln \& Guba, 1985). Both of these standards are socially constructed by epistemic communities. These standards can therefore change. Moreover, these standards can have different meanings, even to members within the same epistemic community or the same person in two different contexts. For example, 0.05 is the threshold for which statistical test? With what kind of data? Similarly, member checking must include which members? And how should the check be performed? These questions identify key features of the meaning of each standard. Intersubjectivity of these standards requires participants agree upon the answers to such key questions. The best test we have of agreement is the ability to coordinate actions that depend upon the meaning. For example, if I ask for the data so I can test for significance, and if you give me the data in the form I expect, then I can be fairly confident you and I have the same test in mind and therefore a shared meaning of "statistical significance." Intersubjectivity, therefore, is best evidenced in localized social exchanges where actions serve as evidence of agreement across subjects.

It is important to note that Habermas's (1985) conception of rational discourse includes both "linguistic and non-linguistic actions," where non-linguistic expressions might include "delays, surgical interventions, declarations [waging] of war, [and] repairs" (p. 8). Both linguistic and non-linguistic expressions communicate, but only linguistic expressions use words to do so. What matters is that the expression effectively makes a claim addressing one of the purposes listed above, and that this claim can be evaluated against shared standards of reasoning.

For examples of the kinds of discourse Habermas (1985) discusses, consider the following pair of climate change discourses. To set context, imagine a city has adopted a climate change adaptation plan that involves spending $\$ 12$ million to raise the elevation of causeways in and out of town. The action of causeway renovation is a non-linguistic claim approximately translated linguistically as, "We believe climate change is real and that this is a right way to deal with it." This statement prompts two different kinds of discourse in local meetings, coffee shops, and newspapers. First is the "theoretical" or truth-finding question, "Is climate change really real?" Second is the practical question, "If it is real, what is the right way to deal with it?" These two questions have different assertion goals and therefore require distinct forms of reasoning. What shapes those distinct forms ought to take would be decided in an "explicative" discourse about each question that clarifies their appropriate form. In all cases, for these discourses to count as discourses, multiple parties must participate, and participation requires their ability to evaluate each other's claims. As Habermas observes, "[My] reflections point in the direction of basing the rationality of an expression on its being susceptible of criticism and grounding" (p. 9).

Expanding on Habermas's (1985) insights, Wright (1995) and Campolo (2005) theorize that 'reasoning together' is the activity of establishing or repairing intersubjectivity about the implications of a claim for the sake of continuing a shared effort. Or, as Campolo puts it, "It is a way of restoring or initiating purposeful coordination to our several actions or behaviors" (p. 38). Purposeful coordination is exactly what is at stake in collaborative projects; without it, a group is unlikely to accomplish its goals. Examples of coordinated action include meeting together, defining a research question, collecting and analyzing data, and submitting an article.

Here's how reasoning together supports such coordinated action. The initial result of a session of reasoning together is an assertion, which is a type of action ("communicative action," according to Habermas, 1985). This initial action then enables a chain of other actions: assertions enable understanding, understanding enables belief, and belief enables actions (see bottom half of Figure 1). This chain must occur for each of the innumerable decisions an interdisciplinary team must make. Moreover, the project itself is the first link in this chain as the understanding it generates should go onto influence beliefs and actions beyond the project.

Collaborative reasoning in research can be triggered by a disruption in any one of these links in the chain of action — originating either within or beyond the project. John Dewey (1910) called such a break "the feeling of a discrepancy, or difficulty" (p. 73), and it is the first step in an inquiry. An ex- 
ample of disruption within the team might come when teammates do not agree on how to complete the data analysis, or when someone doesn't understand what someone else wrote in the manuscript so they can't approve its submission. Disruptions beyond the team might arise even before the team assembles; these might be disruptions that start the team's entire project as an inquiry into an external disruption. For instance, when colleagues in a field no longer understand a phenomenon (e.g., the claims are controversial, incoherent, or absent), the coordinated action of understanding has been disrupted, and this event can manifest as a research question. In another instance, resource users might be at a loss about what to do because they are questioning some long-held beliefs (e.g., they question if climate is stable), and, if researchers are listening to their needs, this distuption in daily life might prompt a research question. Research projects are attempts to restore disrupted chains of action in the world (including disrupted understanding, such as curiosity) by answering research questions, and this requires answering many other kinds of questions within the team's work. Answering questions as a team requires reasoning together.

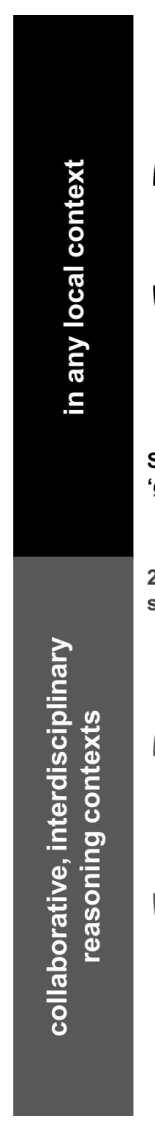

Reasoning together is (linguistic or non-linguistic) discourse in which the participants exchange, evaluate, and assert claims that enable coordinated action in a local context. 1

Reasoning together (expanded) $=$ the co-application and, perhaps, co-revision or even cocreation of intersubjective standards for what counts as a good reasons and inferences in a localized social exchange so that people can continue working together.
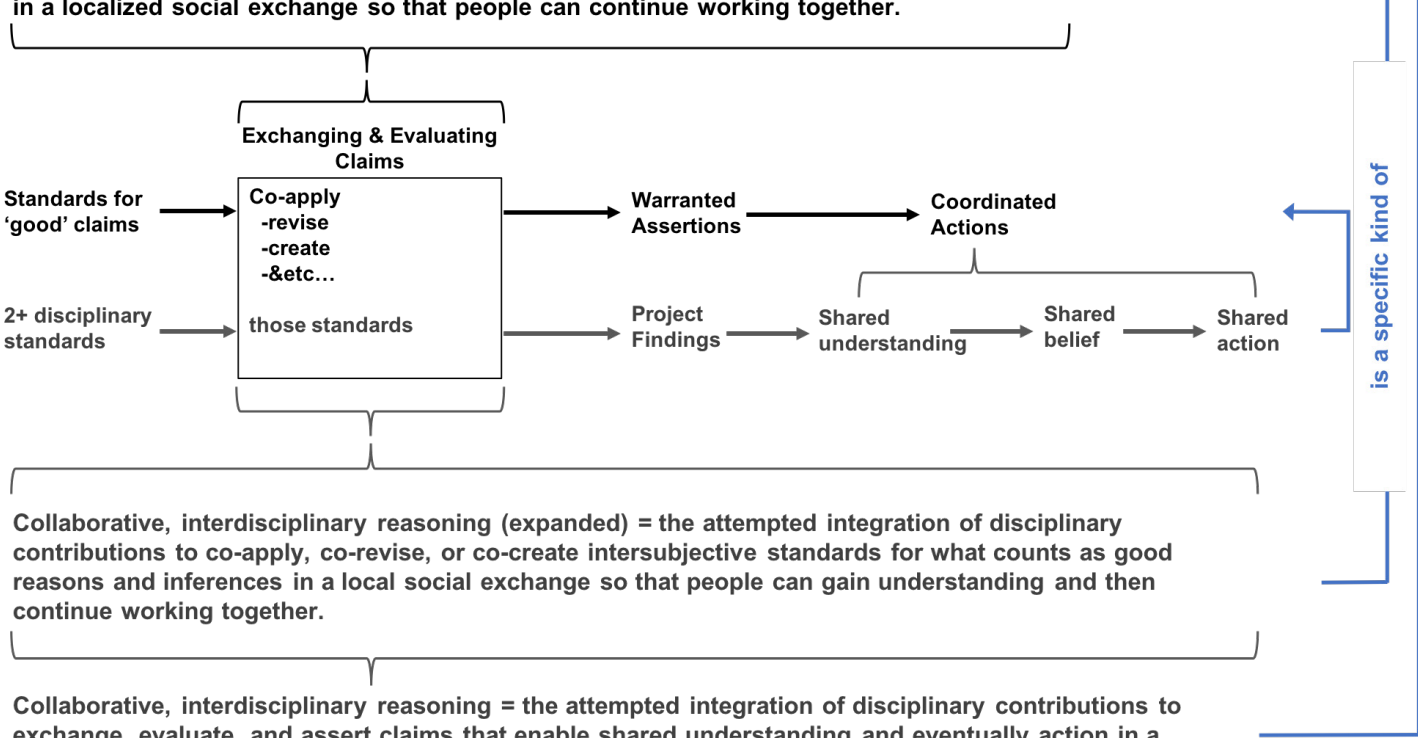
local context.

Figure 1: Reasoning together in any local context (top) vs. collaborative, interdisciplinary contexts (bottom).

Integrating the insights of Habermas, Wright, and Campolo, in the present project I understand reasoning together as follows:

Reasoning together is (linguistic or non-linguistic) discourse in which the participants exchange, evaluate, and assert claims that enable coordinated action in a local context.

This proposition is worth unpacking. Recall that reasoning involves assessing one claim's dependence on other, more well-established claims. To evaluate these claims, participants must agree upon the standards by which they will evaluate them. The following questions arise: What counts as a "supportive" claim? How do we judge when one claim legitimately "depends on" another? What do we accept as "well-established"? If members of a team are not yet on the same page about these stand- 
ards, they need to resolve their misunderstandings using a meta-, "explicative" discourse. Otherwise, they might go ahead and apply a shared or dominant standard in any of Habermas's four other forms of discourse.

Therefore, in order to exchange, evaluate, and assert claims together, participants need shared standards of what counts as good reasons and inferences. Well-supported, shared inferences then enable coordinated action. An expanded definition of reasoning together, therefore, follows:

Reasoning together is the co-application and, perhaps, co-revision or even co-creation of intersubjective standards for what counts as a good reasons and inferences in a localized social exchange so that people can continue working together.

The prefix "co-" specifies that these activities occur collaboratively, through conversation and other forms of communication. Co-application consists of applying existing standards of reasoning. For instance, a team may have already decided that 'good' claims in their project must be based at least partly on inferential statistics. They could then apply that standard to a questionable claim to see how good it is. Co-revision modifies an existing standard to restore shared understanding of it. Cocreation, however, is the synthesis of a new standard from existing, shared understanding. Note that reasoning together cannot create shared understanding ex nibilo; much must already be shared (Campolo, 2005).

This conception of 'reasoning together' emphasizes (1) team members must have shared resources for evaluating a claim and (2) the goal of reasoning depends on the local context of a targeted action. Participants in collaborative research are trying to take an action of assertion that leads to the subsequent action of shared understanding, whether understanding of truth, action, value, authentic expression, or discourse itself. This shared understanding, ideally, enables further coordinated actions beyond the research project, e.g., spending $\$ 12$ million to upgrade causeways.

To clarify relationships among key concepts thus far: We reason to go from understanding less to understanding more by making inferences. We make inferences by evaluating whether some relatively well-established claims support other claims. Evaluating support involves applying standards for what counts as support, where applying such standards may first require creating or revising them. When reasoning as a team, all participants must agree upon and understand those standards. Reasoning then results in warranted, assertible conclusions that enable a series of coordinated actions. Assertion itself is a kind of coordinated communicative action, but it typically serves a more distal action. In a surgery team, that action is a successful surgery. In a research team, that action is shared understanding of a phenomenon. Eventually, shared understanding from research may influence actions beyond the research project, such as a more successful surgery. The top half of Figure 1 charts this definition of 'reasoning together.'

\section{COLLABORATIVE, INTERDISCIPLINARY REASONING DEFINED}

From here, to define CIR we need only specify what it means to reason together in an interdisciplinary way. Given the prevalence and promise of interdisciplinary research described above, a relatively clear consensus has emerged about what it means to be "interdisciplinary." The authoritative definition from the National Academies in their 2005 report (National Research Council, 2005) Facilitating Interdisciplinary Research is widely recognized: interdisciplinarity entails "integrat[ing] information, data, techniques, tools, perspectives, concepts, and/or theories from two or more disciplines or bodies of specialized knowledge" (p. 2). Combining this definition with the above definition of 'reasoning together' suggests the following definition of CIR:

Collaborative, interdisciplinary reasoning is the attempted integration of disciplinary contributions to co-apply, co-revise, or co-create intersubjective standards for what counts as good reasons and inferences in a local social exchange so that people can gain understanding and then continue working together. 
Or, a shorter way to express the same concept:

CIR is the attempted integration of disciplinary contributions to exchange, evaluate, and assert claims that enable shared understanding and eventually action in a local context.

The bottom half of Figure 1 shows how this definition of CIR specifies the more general definition of 'reasoning together.'

Standards for reasoning already exist in most disciplinary discourses, but they must often be revised or created in interdisciplinary discourses because all disciplinarians bring their own standards to the team (Cetina, 2009; Eigenbrode et al., 2007). Disciplinary standards may not only have different thresholds (e.g., $p<0.1$ versus 0.05 ), they may also have different content and meanings altogether (e.g., "significant" = relevant, credible, actionable; versus $p<0.05)$. Co-revision consists in sorting out mismatched understandings of standards, while co-creation consists in establishing new standards. Some teams may be able to co-apply an intersubjective standard right away-perhaps having worked together before. Usually, however, teams will first need to co-revise or co-create such a standard through the process of explicative discourse.

As Habermas (1985) observed, a discourse that makes claims can be understood as an argument, where the more established claims are premises and the inferred claim is the conclusion. A reasoning team is trying to craft a cogent argument all of its members endorse. The argument contains premises each interlocutor can evaluate for "allegations of support" of the conclusion (Wright, 1995, p. 570), and the conclusion captures the result of co-applying the standard to those premises. In some cases, the conclusion will itself be a standard to co-apply in another argument. In such cases, as an instance of explicative discourse, the argument is co-repairing or co-creating a shared standard for later reasoning. For example, the city council that approved the causeway renovation probably had an earlier meeting or series of meetings in which they decided that conclusions about climate change and what to do about it require certain kinds of evidence (e.g., regional climate models, climate risk assessment). Therefore, when they got this evidence, they were able to make an argument asserting climate change is real and causeway renovation is an appropriate next step. In an interdisciplinary group (perhaps the city council qualifies), the argument premises will often be crafted from various disciplinary contributions. The example in the next section illustrates how collaborative, interdisciplinary conversations can be understood as instances of CIR. It focuses specifically on explicative discourse - the co-creation of standards for group reasoning about another topic.

First, though, it is crucial to emphasize that interlocutors need not succeed in achieving intersubjectivity to engage in CIR. All three philosophers above emphasize, as Wright (1995) observes, "The practice of giving reasons is of value in our deliberations when and because we are equipped [emphasis added] to evaluate the allegation of support [of a reason]" (p. 570). When we are not so equipped, reasons don't help much. In other words, it is quite possible to give reasons in a way that is notvaluable and nevertheless be engaged in reasoning together. We often reason together quite poorly. Defining exactly what it means to reason together well or poorly in CIR remains a future project, but some warnings about the general process of reasoning together apply.

Wright (1995) and Campolo (2005; Campolo \& Turner, 2002) stress that we are equipped to evaluate allegations of support when the standards by which we evaluate them are (in my paraphrasing) (a) shared, (b) relevant, and (c) informed. If any one of these three criteria is absent, then we ought not to reason together. Here's why.

There are two options when participants realize they do not share enough foundational, relevant, informed commitments to make reliable inferences that solve the problem. One option is to stop reasoning and try another coordination approach, such as following orders. The other option is to continue reasoning, but this option is dangerous. To continue reasoning using claims they do not hold or understand, participants must create an appearance of informed consensus. This illusion can be constructed in at least two ways: either stronger participants force weaker participants to adopt 
their views and/or participants feign understanding. In the first case, great harm might be done through epistemic oppression and valuable understanding might be suppressed that could have helped solve the problem (Dotson, 2012; 2014). In the second case, which might also be a form of testimonial injustice (Dotson, 2011), it is unlikely the group will solve the problem and this could be harmful in itself. In addition, any success participants might have will be due to luck-good inferences will have nothing to do with it. This can also be harmful as it may reinforce bad reasoning habits (Campolo, 2005).

Collaborators must therefore have quite a bit in common before reasoning together becomes possible or useful. While it is possible to have an explicative discourse, i.e., to reason together to co-create a shared standard for another discourse, it is not possible to have explicative discourses about explicative discourses ad infinitum. We must, eventually, agree on some standard for reasoning to get off the ground. These basic shared standards arise from our shared experiences; for instance, our experience as academics. As Campolo (2005) puts it,

Reasoning together in a fruitful way depends upon our existing shared practice, shared knowledge, and shared competence. Under the right conditions, reasoning together can restore that intersubjectivity. Under almost no circumstances can reasoning together create that intersubjectivity where it does not already exist. (p. 45).

Thus, to judge whether a group is reasoning well or poorly, we must know the nature of their shared background. Therefore, the example below goes so far as to affirm reasoning did succeed to some extent, but a full evaluation is beyond the scope of this study.

\section{COLLABORATIVE, INTERDISCIPLINARY REASONING EXEMPLIFIED}

CIR can be found in many places. The Appendix documents an excerpt from a transcript of a Toolbox workshop as well as the analysis I performed on the transcript, described below. Toolbox workshops host lightly facilitated, cross-disciplinary team discussions about project-related work. The facilitator rarely speaks, but the written instrument each participant completes provides some structure in the form of a menu of project-related assumptions participants can discuss at will. (For more information about the Toolbox Dialogue Initiative, formerly known as the "Toolbox Project", see O'Rourke \& Crowley, 2013). The excerpt in the Appendix is a conversation thread about 40 speaking turns long, including minor interruptions and affirmations such as "Mmmhmm," and "Right" excluded from this analysis. In this thread, interlocutors discuss what counts as modeling in their interdisciplinary project. They evaluate and integrate each other's claims into a coherent argument supporting a conclusion about modeling that allows them to go on together. Of the twelve team members present, only three participate in this thread: a sociologist, a hydrologist, and an engineer. They integrate contributions from their three disciplines into five argument premises (P1-5) that together support a single conclusion about what counts as modeling in their project.

This section begins by overviewing the argument. Next, it describes the methods used in reconstructing the argument and then the reconstruction itself, i.e., how each premise is developed in the dialogue. Lastly, the section concludes by showing how this example of explicative discourse enables future coordinated action for the participants. This section is an example other analysts can follow with interdisciplinary conversations wherever they occur.

\section{ARGUMENT OVER VIEW}

The numbers in parentheses below after a given premise refer to speaking turns that contribute to that premise. The first premise is mostly implicit in the dialogue, which is indicated by brackets. (Noteworthy: the sociologist does utter a few words gesturing in this direction). Similarly, the conclusion does not appear in any speaking turns because no one spoke the entire conclusion out loud; it 
also appears in brackets. However, implicit conclusions are not necessarily unreasonable or problematic. Explicit articulation is not logically required since the conclusion follows from the premises, which were already well-established, and it summarizes the general position that participants in the excerpt constructed.

P1. [The practices of the people here decide what modeling is in our project.] $(64,66)$

P2. Everyone here uses statistics with empirical observations to build their models. $(66,68,69$, $79,89,91)$

P3. Hydrologists and engineers use statistics to correlate inputs and outputs according to processes they already know. (70, 75-79, 83, 85, 87)

P4. Sociologists use statistics to discover processes. $(70,77,81,85,92,94,96,98,100)$

P5. These two practices both use the input-process-output framework although their operationalizations of the framework differ. $(72,74,88,91,103,104)$

C. [Therefore, modeling in our project involves using statistics with empirical observations to operationalize the input-process-output concept.]

With this conclusion, conversational participants are now on the same page about what modeling is in their project, enabling them to continue modeling together. Because their modeling practice was at stake, interrupted by misunderstanding, they co-revised their standard for what counts as a reasonable claim about modeling. Now, they could co-apply this standard to their shared modeling practices in future interdisciplinary dialogues - until another disruption requires them to co-revise. Their conclusion is an inference that allowed them to go from understanding less about modeling to understanding more. It is an assertion that enables future chains of coordinated action.

\section{ARGUMENT RECONSTRUCTION METHODS}

Reconstructing arguments from ordinary language-especially un-rehearsed dialogues - is difficult and controversial. Pragma-dialectical argumentation scholars recognize the tension between getting the reconstruction right while also assuming the speakers are making the strongest argument possible, consistent with their argumentative intentions (van Eemeren, Garssen, Krabbe, Henkemans, et al., 2014a). This assumption requires an analyst to fit the speakers' words into a cogent argument form-even if it is not the form in which the speaker presented claims. Indeed, everyday conversations rarely proceed as linear arguments. In most cases, one must give the speaker the benefit of the doubt when it comes to re-constructing a cogent argument but also capture the conversational moves actually used to argue. That is, the analyst must be charitable but also descriptively accurate. There is no easy to way to resolve the tension between accuracy and charity, although pragma-dialectical (schematic) reconstructions combined with conversation analysis can help, and that is what I have tried to do here (Sandvik, 1997). Nevertheless, we can think of argument reconstruction as more of an art than a science. Others may see a different argument in the excerpt than the one I present below.

However, any such disagreement merely illustrates the proposition that reasoning together is about exchanging and evaluating reasons for one's assertions. Specifically, some might give reasons to disagree with the reconstruction, underscoring that we rely upon reason-giving in research discourse and this difficult task requires balancing accurate and charitable interpretations of what others have said. Thus, the main purpose of this example is not to get the reconstruction "objectively right" (if there is such a thing). The purpose, rather, is to illustrate collaborative, interdisciplinary reasoning, whether through the example itself and/or how we talk about it.

In this reconstruction the following guiding principles apply.

1. The definition of CIR identifies four nodes or knots in the reasoning tapestry: discussants, disciplines, premises, and a conclusion that increases understanding and eventually leads to action. 
2. Brief verbal affirmations such as "Mmmhmm," and "Right" are not content contributions but rather indicate acceptance, and so they are excluded from the analysis.

3. The remaining, substantive speaking turns may contain more than one distinct idea.

4. Each distinct idea is coded as a separate "contribution."

5. The speaker's own disciplinary identity indicates which disciplinary perspective is driving the contribution, unless the speaker explicitly notes they are taking on the perspective of another discipline or disciplinarian.

6. These disciplinary contributions contribute to argument premises, and the premises a conclusion.

7. The premises and conclusion are assumed to be grammatically complete, contextually meaningful, and logically coherent (i.e., "well-formed") claims.

8. A well-formed claim may or may not be spoken aloud. In cases where it is not, the analyst supplies the missing pieces by surmising what the speakers intended to say or believe they did say. Listening to the audio recording can help in resolving ambiguity.

The full application of these principles to the excerpt is documented in the Appendix.

\section{ARGUMENT RECONSTRUCTION}

\section{P1. [The practices of the people here decide what modeling is in our project.]}

Understanding the origin of Premise 1 requires first looking at the dialogue's context. Participants requested a Toolbox workshop because they wanted to get on the same page about key concepts in their project. Thus, this excerpt about modeling takes place in a conversational context designed to help them increase mutual understanding, which includes mutual understanding about what modeling is in their project. The assumption behind the dialogue is that the people present have a significant role to play in determining how things are understood within their project. In fact, the sociologist implies as much when he opens the excerpted dialogue:

Sociologist $(64,66)$ : "Well one of the things I found working with many of the people in the room is a term I'm still trying to wrap my mind around, that I don't think we all use the same way is the word 'modeling... We actually confronted this one when we tried to write our grant."

The sociologist references use of the term "modeling" in their proposal writing process, indicating that the following discussion is about use of the term in this project by people participating in the project. The others take up this conversation, below, implying they agree with this first premise.

What has happened is that the participants immediately applied a shared, unspoken standard about what is assertible by the sociologist. What is assertible seems to be whatever has been experienced by anyone in the group-individually or collectively. It is not clear how they came to share this assertibility standard. They may have affirmed the validity of each other's experiences in previous discussions, or they may simply share that assumption based on their shared lifeworld as academics, where (usually) one's expertise is not questioned by those from other disciplines. When applying this standard to his claim, the sociologist here is not speaking as a sociologist but more generally as a member of the project. Indeed, Figure 2 shows P1 is comes from no particular disciplinary perspective. 


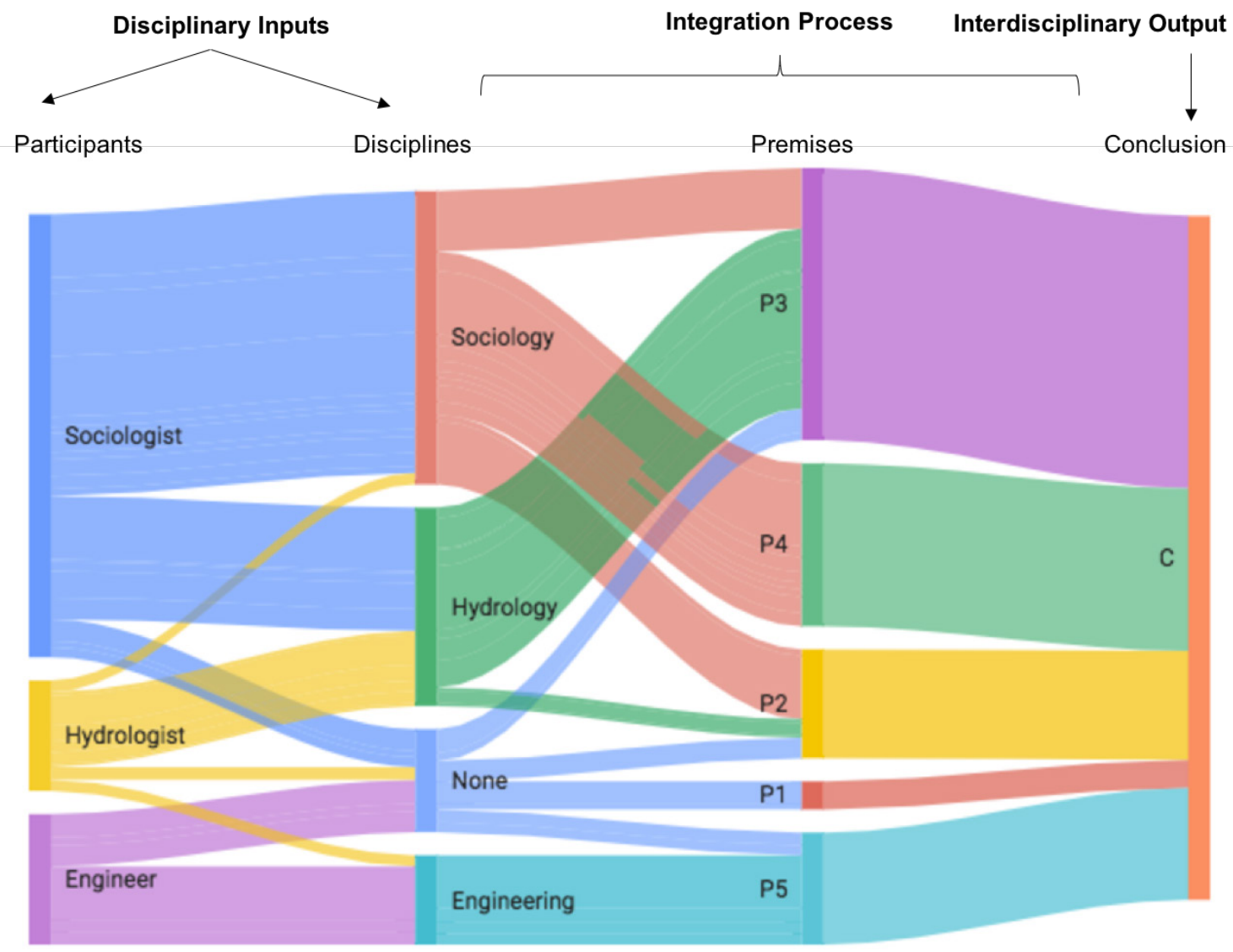

Figure 2: Flow of words (and therefore reasons) from speakers to disciplines, premises, and conclusion in the dialogue excerpt (26 speaking turns, 34 contributions, 1294 words). The width of the link represents the number of words.

\section{P2. Everyone here uses statistics with empirical observations to build their models.}

Premise 2 takes quite a while to become a full thought in the dialogue. Not until speaking turn 89 do participants discover what exactly they all have in common when modeling. They spend much of the dialogue trying to find the commonality by showing how they use terms related to modeling, such as "calibration" and "significance." For example, the Sociologist explains that when he models,

Sociologist (66): ... we [Sociologists] go and do a fairly standardized set of mathematical type things that say, ok that is, that explains this much of what we were trying to explain, this well or with this much degree of confidence....

Sociologist (68): [cont.] Um, but you're actually inferring sort of this significance of relationships and so.

Hydrologist (69): [overlap] Well you just described what we do.

In this brief exchange, the hydrologist and sociologist agree that for them, significance means mathematically significant, a definition that likely refers to statistics given the use of the terms "degree of confidence" and "significant." The engineer never disagrees with this conclusion, suggesting that it also describes his practice. A longer exchange (75-89) centers on the term "calibration," but in fact the process of calibration is so technical they cannot fully compare the various meanings-in-practice during this brief dialogue. They are satisfied to know calibration eventually ends by determining the statistical significance of their empirical observations. 
By comparing and contrasting related terms such as "calibration" and "significance," the interlocutors (the sociologist, hydrologist, and engineer) can triangulate on where the focus term, "modeling," fits in their respective meaning structures (Mohr, 1998). In locating the target term in relation to other terms, they can discern its core meaning: they examine which terms it is related to in the same way in the meaning structures of all participants. They decide that the core feature of modeling for them is use of statistics with empirical observations.

Sociologist (66): "[The way] we model in the social sciences - some of us do - is basically an exercise of developing some theoretical models and testing them against the world and seeing how well that model fits."

Hydrologist (89): "But what you described is what you do for a model anyway, you're approach to modeling? I'm just sitting here going, hmmm yep."

Again, we see the participants applying their shared standard for what is assertible, namely whatever has been experienced by the participants. When they apply this standard to the anecdotes given by the sociologist and hydrologist, they establish a new claim about the necessary role of statistics. Now that they know what they have in common, they must articulate their differences to develop an integrative definition of modeling. Figure 2 shows P2 is an interdisciplinary premise, established by sociology, hydrology, and a general perspective integrated into a coherent claim.

\section{P3. Hydrologists and engineers use statistics to correlate inputs and outputs according to processes they already know.}

Premises 3 and 4 take even longer than Premise 2 to formulate. In fact, not until the engineer introduces the boundary-crossing metaphor of a "box" do the sociologist and hydrologist/engineering camps articulate their practices in a shared language or terminology so they can compare them.

Engineer (72): "I think one aspect of it is, there's like, think about it as a box. There's inputs, and there's outputs. One type of model is trying to correlate those and show how inputs match with the outputs just however mathematically or statistical description. The other type is processes."

Most modelers are aware of the box metaphor. It provides a common framework within which are different components — inputs, processes, and outputs (the IPO framework) —with different roles for different modelers. Still, interlocutors in this example struggle for a while to locate each other within this framework. Applying their "whatever we've experienced" standard is not as easy as it was in the first two premises. The difficulty seems to stem from the fact that, in contrast to their common use of statistics, they either don't use the IPO framework to understand their own modeling practices or, if they do, they use it differently from each other. Reconciling those different uses takes some conversational work.

Taking up the engineer's "box" proposal, the hydrologist leans into the IPO framework to describe her modeling practice in detail in speaking turns 75 and 77 . She ends with a provocative summary, "We [hydrologists] have some fundamental processes we know occur." The sociologist immediately understands and critiques this sort of modeling, signaling that this approach is somehow essential to the differences between sociological and hydrological IPO modeling; premises 3 and 4 co-evolve. The engineer identified two ways to use the IPO framework: (1) correlating inputs and outputs, and (2) specifying the processes. Once it becomes clear the sociologist does the latter, it is simultaneously clear the hydrologist and engineer do the former. Hence the fullness of Premise 3 depends conversationally but not logically upon Premise 4 . Figure 2 shows P3 is also an interdisciplinary premise, established by the same contributing perspectives as $\mathrm{P} 2$, but from different utterances. The figure also shows that P3 takes the most words and therefore the longest to establish; it proved to be the trickiest premise for everyone to understand. This makes sense since P3 initiated P4 yet also depends conversationally upon it. 


\section{P4. Sociologists use statistics to discover processes.}

Because Premises 3 and 4 unfold simultaneously, it is worth requoting the hydrologist's summary from speaking turn 77 more completely:

Hydrologist (77): "[You sociologists are] trying to - your conceptual knowledge is trying to get put together somehow. We [hydrologists] have some fundamental processes we know occur [in the world], so we have to figure out whether or not we're missing some [in this model]."

This comment distinguishing the two modeling practices makes more sense later in the dialogue, after discussing the particular practice of calibration:

Sociologist (92): “We [sociologists] just don't start with any process relationships, those are all to be discovered."

That is, if hydrologists and engineers are correlating inputs and outputs because they already know (a potential list of) the processes involved, then what is different is that sociologists do not yet know their processes. One can see how this integrated understanding of modeling would serve their project very well because the disciplinary practices complement each other. Figure 2 shows P4 is actually a disciplinary claim from sociology; the sociologist is, after all, speaking for himself. However, we know he is responding to hydrological and engineering perspectives, so again we see that P4 depends conversationally but not logically upon P3. P4 therefore takes almost as many words as P3 to establish. Applying the "whatever we've experienced" standard to this claim takes as much effort as that for the previous claim.

\section{P5. These two practices both use the input-process-output framework although their operationalizations of the framework differ.}

Finally, now that participants have identified their common use of empirical statistics and their different roles in the IPO framework, they need to show how the commonality and the difference are both part of the same practice, namely modeling. This is a bit of a conversational formality as they have been assuming all along that these practices are part of modeling. But they are not satisfied until they explicate exactly how those practices relate. Near the end, the hydrologist has an epiphany that brings it all together:

Hydrologist (103): "Hey! So maybe it's just that we all come up with conceptual models similarly, but it's [the difference is] the actual implementation of it?"

Sociologist (104): "Seems to be. It's yeah the practice of what we actually do when say we go out and model."

The epiphany rests on the realization that the IPO framework is a conceptual model shared by both camps; everyone is assuming there are inputs, processes, and outputs in their models. However, when it comes time to build a model—to operationalize it—participants make different assumptions about what inputs, processes, and outputs to include. This is another application of the "whatever we've experienced" standard. In their experience, hydrologists and engineers (in this dialogue) assume they know what processes could be involved, so what is to be discovered through the model is to what extent the inputs and outputs correlate based on which processes are actually involved and what values their parameters have. Sociologists, on the other hand, do not assume they know which processes could be involved; "those are all to be discovered." In this way, both camps model using the IPO concept although they operationalize it in two different ways - but always with statistics! Figure 2 shows P5 is also integrative, established by the engineering and general perspectives present. 


\section{C. [Therefore, modeling in our project involves using statistics with empirical observations to operationalize the input-process-output concept.]}

The argument's conclusion follows logically and immediately from its five premises; essentially, participants have already reached this conclusion after expositing premise 5. The conclusion is a generalization from two kinds of modeling to all modeling that occurs or will occur in the project. Specifically, this takes the form of an inductive argument, also known as an inductive generalization. Such an argument establishes that certain features shared by a sample of members of a set are likely shared by all members of that set. Just how likely this prospect is depends upon how representative the sample is of the set. In this case, our discussants believe they are remembering past instances of their modeling practices that accurately represent the types of modeling they will do in the future. This is what justifies their application of the "whatever we've experienced is assertible" standard. Time will tell how accurate this belief is, but for now they have good reasons to believe their memories accurately reflect the past and predict the future. Therefore, this inductive argument yields a strong, cogent, interdisciplinary conclusion that allows them to move forward with modeling. Figure 2 shows that all five premises, and therefore the total volume of words spoken in the exchange, contribute to the conclusion. Because these premises were established by several disciplines, and because we know the premises and conclusion are cogent, Figure 2 shows us that interdisciplinary integration resulted in the conclusion discussed above.

This conclusion (of an explicative discourse) functions as a standard they can apply in future forms of discourse. It is a standard that was co-created from the application of another standard that was already shared. If participants did not already share that standard, they would not have been able to have this conversation. In other words, instances of CIR depend upon shared, intersubjective standards that must pre-exist the focal question. Such pre-existing standards can be established through other rounds of CIR or shared lifeworld experiences that create shared assumptions.

\section{ARGUMENT VISUALIZATION}

Visual analysis complements argument reconstruction. Argument reconstruction highlights the logical structure and rhetorical presentation of the discourse. In doing so, it de-emphasizes the amount of conversation that occurs, the overall sources and locations of integration, and who plays particular roles across the entire argument. A parallel sets chart, on the other hand, emphasizes those very things (Figure 2). A parallel sets chart illustrates flows between sets, e.g., visualizing the flow of money through accounts or energy through trophic levels. (For the basics of parallel sets charts, see https://datavizcatalogue.com/methods/parallel sets.html. Sometimes these are also called Sankey diagrams, e.g., https://developers.google.com/chart/interactive/docs/gallery/sankey.)

In our case, we are tracking the reasoning process from individual participants to a shared conclusion. The "sets" are sources and sites of inference along the way, viz., (1) participants, (2) disciplines, (3) premises, and (4) argument conclusion. (Participants are separate from disciplines since participants can infer the perspective of several disciplines.) The "flow" is the reasons asserted, viz., words uttered. By tracking the words through the reasoning process, we can visualize sources and sites of integration and participant reasoning roles in the entire conversation at a glance. These quantitative insights complement the qualitative argument reconstruction, helping analysts and practitioners identify which disciplines tend to make certain kinds of contributions to the integrative work, and who tends to represent those disciplines in what ways.

While not the only way to visualize reasoning, this set-and-flow chart falls directly out of the definition of CIR given above. In that definition, CIR is the transformation of disciplinary contributions into an interdisciplinary conclusion through the exchange of reasons. In this example, words flow from participants, pictured on the left side of the chart (Figure 2), through various disciplines and premises to the conclusion, on the right side. The word flows represent the exchange, evaluation, and assertion of claims between participant-disciplines (inputs), coherent premises (process), and a con- 
clusion or warranted assertion (output), per the IPO model of integration offered by O'Rourke and colleagues (O'Rourke et al., 2016).

Note that the chart alone does not visualize integration or intersubjectivity; those must be assessed through the argument reconstruction. To wit, just because two disciplinary contributions are relevant to the same premise does not necessarily mean they are integrated beyond a mere, multidisciplinary 'stapling together.' We must examine the construction of the premise to assess its integration. Likewise, just because two people contribute to two disciplines which contribute to a single premise does not necessarily mean the people each understand that premise in the same way. We must carefully read the transcript. Integration and intersubjectivity are qualities of the exchange, not quantities that can be charted. We can only locate integration and intersubjectivity in the chart if we use our qualitative knowledge of what the chart represents.

While we cannot use the chart without the argument reconstruction, the argument reconstruction can stand alone as evidence of CIR. However, because it pictures the entire exchange at once, the chart does make some dynamics of CIR more visible than in the reconstruction alone.

Figure 2 helps us identify disciplinary sources of integration and participant reasoning roles. We see the conversation takes 1294 words, which is not very many, so we must keep that in mind when interpreting the chart. The colors in Figure 2 identify the originating nodes; therefore each node has a unique color. (Remember that participants are distinct from disciplines, so the sociologist has a different color from sociology). This helps us track who or what is contributing to a given node.

Through the chart we can quantify both the number of disciplines contributing to integration points and also the volume or amount of their contribution. This approach may help evaluate the breadth and/or depth of the interdisciplinarity, depending on how those constructs are measured (Kelly, 1996).

Figure 2 also showcases clues about conversational roles other studies have shown are important for interdisciplinary communication: dominators (Bondy, 2010; Reed, 2008), boundary spanners (Klein, 2014a), and integration specialists (Bammer, 2013). Figure 2 shows the sociologist speaks most; he may be a controller or dominator in this exchange. The reconstruction can help us interpret the nature of his control. Figure 2 also shows the hydrologist is the most flexible thinker as she contributes to all perspectives in the exchange; she acts as the boundary spanner with interactional expertise (Collins \& Evans, 2002). The engineer may be the integration specialist as nearly one-third of his words fall into a general perspective that applies to all parts of the argument, except P3. Indeed, most of the engineer's words contribute to P5, which is the final premise needed to tie all the others together in a coherent, cogent conclusion. Thus, we see Figure 2 not only identifies sources and sites integration, it also aids the quick, visual identification of key conversational roles that can spark further analysis or team interventions. Together, the parallel sets chart and argument reconstruction provide a quantitative and qualitative understanding of the nature of interdisciplinary integration in this discourse. The new definition of CIR proposed above makes these analyses possible.

\section{FROM DISRUPTION TO CONCLUSION TO ACTION}

The above dialogue excerpt is an example of what Habermas (1985) calls "explicative discourse," which is discourse about the standards for discourse, as noted above. Habermas explains,

Explicative discourse [emphasis original] is a form of argumentation in which the comprehensibility, well-formedness, or rule-correctness of symbolic expressions is no longer naively supposed or contested but is thematized as a controversial claim. (p. 23)

"Thematized" means abstracted from specifics into a principle that can be interrogated. In this case, specific instances of purportedly "well-formed" definitions of modeling are abstracted into a general definition of modeling for their project. Another way of describing this form of discourse is a shift to a 'meta-level'-from the current topic to bow we ought to talk about the topic. The team is not trying to 
model right now; they are talking about how to model within their project. This shift to explicative discourse is triggered because they keep using the term in different ways, disrupting their shared understanding of modeling in their project. The sociologist opens this discussion by noticing this disruption and bringing it to the group, shifting discourse from a naïve supposition to a controversial claim. As a result, they want to know what counts as a good reason to trust each other's modeling approaches. Explicative discourse, like any other discourse, becomes interdisciplinary when these standards for 'good reasons' are created or revised through the integration of disciplinary contributions. As the example illustrates, choosing a team modeling approach is a common example of interdisciplinary explicative discourse, and therefore is also an instance of CIR.

Now that they have an intersubjective standard for what counts as modeling, they can go on with modeling; their practice will require co-applying this standard in other kinds of discourse. For example, they might try to get at the truth of something, and therefore apply this standard of modeling in a future theoretical discourse. They might ask, "What could be the impact of residential water use on this aquifer?" Collaborative consideration of this question will be another instance of CIR, but it is also the action-outcome of the first instance. Their first instance of CIR established what modeling is. This step will enable them to take the action of modeling the aquifer, which will be the second instance of CIR. In short, since actions count as non-linguistic expressions, the outcome of one discourse is another discourse, and so on. Humans are in ongoing conversation with each other, and interdisciplinary research is no exception.

\section{COLLABORATIVE, INTERDISCIPLINARY REASONING QUALIFIED}

Of course, to introduce the concept of CIR I chose an example that successfully reached an integrated, logical conclusion (in only 6 minutes of conversation!). Its brevity might lead one to believe CIR is easy. It is not. Toolbox transcripts also contain muddled, confused arguments that never resolve. Dialogical impasses can be caused by many factors, including: the illusion of agreement; the illusion of disagreement; fuzzy concepts; information overload; implicit (or explicit) bias; competing values; moral dilemmas; incommensurable epistemologies and ontologies; and, almost inevitably, the jerk in the room. Freeing these impasses requires first diagnosing which factor-among others-is the root cause. Thinking in terms of CIR can help with this diagnosis. By tracking which disciplinary standards are being integrated into an argument and how, a theorist or practitioner will find the point of impasse. Several tracking questions aid this process: Does everyone agree on the type of discourse we're having right now (e.g., explicative, practical)? If so, which reasons nevertheless fell flat? Who disagreed or got confused? Gently digging into the sticking point like a surgeon examining a wound will reveal the root causes. At bottom may be a difference in meanings, values, goals, or personalities that can be resolved. One must continue querying reasons for the impasse and considering answers from many perspectives. The solution to problems with CIR is often more CIR, increasingly targeted where there is lack of intersubjectivity.

However, sometimes more reasoning isn't the solution. For instance, it is not clear that reasoning alone would be enough to involve the other nine participants in the exchange analyzed above. Perhaps some did not speak due to testimonial quieting or smothering by more powerful members (Dotson, 2011). If so, more CIR would simply perpetuate this harm, making things worse. Perhaps some did not agree with the assumed standard of assertibility ("whatever we've experienced is assertible.") This may be a deep disagreement that is unresolvable; no matter what is said the disagreement would remain and participation would be divided. Although it was successful, the excerpt above is not perfectly ideal; intersubjectivity only extended to one-fourth of the group members.

While a lot of CIR isn't as quickly resolved as the example I analyzed above, unresolved attempts at CIR are not complete failures. In the process of genuinely engaging one another's disciplinary standards, we learn a lot that will help us down the road - so long as we keep an open mind. We learn intellectual humility, charity, and patience (Ferkany \& Whyte, 2011). We learn new vocabulary words (Jeffrey, 2003). We learn who is motivated by what (Boix Mansilla, Lamont, \& Sato, 2015). We learn 
how to midwife half-formed ideas (Burnyeat, 1977; Plato, 369 BCE/1997, 148e-151d). By building these and other capacities (Salazar, Lant, Fiore, \& Salas, 2012), we may eventually be able to integrate our reasons into a shared assertion. But perhaps, more importantly, we become better people along the way.

\section{CONCLUSION}

This article has argued that CIR entails integration of disciplinary contributions to co-apply, corevise, or co-create intersubjective standards for what counts as 'good' reasons and inferences in a team research project. The extended example illustrates this definition. Disciplinary integration is the intended consequence of people from different disciplines trying to reason together. As Habermas, Wright, and Campolo conceive of it, reasoning together requires intersubjective standards for evaluating claims. These intersubjective standards constitute standards for reasonableness in the dialogue, whether talking about reasonable standards of modeling, evidence, methodological adequacy, advocacy, or figure design - to name a few areas of possible conflict in research teams. Achieving such intersubjectivity requires teammates to integrate their respective standards for epistemic (e.g., truth, justification) and non-epistemic success (e.g., justice, feasibility) as well as the meaning of shared concepts, because these standards and meanings often vary in different disciplines. That is, CIR is sensitive not only to the purpose of the dialogue but also to the epistemic cultures of the interlocutors. Engineers, for example, employ different standards of reasonableness and meaning than sociologists.

To conclude, CIR is a unique instance of reasoning together that has heretofore been undertheorized by both argumentation theorists and scholars of interdisciplinarity. While all instances of reasoning together depend upon intersubjectivity, as shown above CIR co-applies, co-revises, or cocreates that intersubjectivity by integrating disciplinary contributions. Identifying the reasoning moves within communicative actions facilitates intersubjectivity, enabling both theorists and practitioners to more effectively diagnose dialogical impasses and analyze the structure of interdisciplinary inferences. CIR is the engine of knowledge integration in interdisciplinary teams, but it doesn't always work well. Nonetheless, if we can better understand the mechanism, we can better understand and improve the transformation of disciplinary contributions into interdisciplinary insights.

Furthermore, understanding CIR could also foster better understanding of transdisciplinary reasoning. Widely regarded as a transformative form of interdisciplinarity (Klein, 2014b), transdisciplinarity is compatible with the definition of CIR above, leading to an expanded definition of CTR integration in which disciplinary contributions result in a new paradigm — a novel kind of standard for exchanging and evaluating reasons. Given this novelty, we can perhaps view CTR as creative while CIR as recreative. Both types of collaborative reasoning rely upon the ability of participants to assess the cogency of claims being made in dialogue and to assert a conclusion with one voice.

At the same time, if transdisciplinarity is understood as collaboration between academics and nonacademics (Klein, 2014b), speaking in unison and in academic discourse is not necessary. Shared standards of reasoning then include different professional and cultural forms of knowledge. Inputs to Figure 1 for this form of CTR will differ from those in transformative CTR or in CIR. The process may also differ if integrated, univocal conclusions are not the goal. If multivocality is an important end (Suthers, Lund, Rosé, Teplovs, \& Law, 2013), the only standard of reasoning everyone must adopt may be "Each to their own." This sort of reasoning together may be sufficient for some kinds of coordinated action, such as university and private entities sharing space in the same building.

More work remains to thicken the construct of CIR by relating it to other "cognitive" or "learning" type constructs in interdisciplinarity literature (Boix Mansilla, 2010; Boix Mansilla et al., 2015; Derry et al., 2013; Nikitina, 2005), as well as more specific types of argumentation from the argumentation and reasoning literatures (Juthe, 2015; van Eemeren, Garssen, Krabbe, Snoeck Henkemans, et al., 2014b; Walton, Reed, \& Macagno, 2008). Future research should then articulate what it means to do CIR well or poorly. Recent work on the role of values in setting scientific standards will be helpful 
here (e.g., Douglas, 2009; Elliott, 2017; Winsberg, Huebner, \& Kukla, 2014), along with work on epistemic harm (e.g., Dotson, 2012; Fricker, 2007) and ignorance (e.g., Ortega, 2006; Piso et al., 2016; Tuana, 2006). From here, we will be able to evaluate instances of CIR and identify areas for improvement. These areas for improvement can then be matched to new or existing team science tools. From the other direction, we can understand why certain tools are or are not effective by examining how they enable or inhibit good CIR. All of these research efforts will benefit from the sort of close conversation analysis of real team discourses exemplified in this paper (Choi \& Richards, 2017). In summary, developing the theory and analysis of collaborative, interdisciplinary reasoning is a necessary step in realizing the promise of interdisciplinary research.

\section{ACKNOWLEDGMENTS}

The author gratefully acknowledges the assistance of Michael O'Rourke with drafts of this article, as well as feedback from Chris Campolo and three anonymous reviewers.

\section{REFERENCES}

Augsburg, T., \& Chitewere, T. (2013). Starting with worldviews: A five-step preparatory approach to integrative interdisciplinary learning. Issues in Integrative Studies, 31, 174-191.

Bammer, G. (2013). Disciplining interdisciplinarity. Canberra: Australian National University E Press. http://doi.org/10.2307/j.ctt2jbkj5

Boix Mansilla, V. (2010). Learning to synthesize: The development of interdisciplinary understanding. In R. Frodeman, J. T. Klein, \& C. Mitcham (Eds.), The Oxford handbook of interdisciplinarity (pp. 288-306). New York City: Oxford University Press.

Boix Mansilla, V., Lamont, M., \& Sato, K. (2015). Shared cognitive-emotional-interactional platforms: Markers and conditions for successful interdisciplinary collaborations. Science, Technology \& Human Values, 1-42. https://doi.org/10.1177/0162243915614103

Bondy, P. (2010). Argumentative injustice. Informal Logic, 30(3). https://doi.org/10.22329/il.v30i3.3034

Brown, V. A., Harris, J. A., \& Russell, J. Y. (2010). Tackling wicked problems through the transdisciplinary imagination. Washington, D.C.: Earthscan.

Burnyeat, M. F. (1977). Socratic midwifery, Platonic inspiration. Bulletin of the Institute of Classical Studies, 24(1), 716. https://doi.org/10.1111/j.2041-5370.1977.tb00363.x

Campolo, C. (2005). Treacherous ascents: On seeking common ground for conflict resolution. Informal Logic, 25(1), 37-50. https://doi.org/10.22329/il.v25i1.1043

Campolo, C., \& Turner, D. (2002). Reasoning together: Temptations, dangers, and cautions. Argumentation, 16(1), 3-19. https://doi.org/10.1023/A:1014958422056

Cetina, K. K. (2009). Epistemic cultures. Cambridge, MA: Harvard University Press.

Choi, S., \& Richards, K. (2017). Interdisciplinary discourse. London, UK: Palgrave MacMillan. https://doi.org/10.1057/978-1-137-47040-9

Collins, H. M., \& Evans, R. (2002). The third wave of science studies: Studies of expertise and experience. Social Studies of Science, 32(2), 235-296. https://doi.org/10.1177/0306312702032002003

De Grandis, G., \& Efstathiou, S. (2016). Introduction-Grand challenges and small steps. Studies in History and Philosophy of Science Part C: Studies in History and Philosophy of Biological and Biomedical Sciences, 56, 39-47. https://doi.org/10.1016/j.shpsc.2015.11.009

Derry, S. J., Schunn, C. D., \& Gernsbacher, M. A. (2013). Interdisciplinary collaboration. New York, NY: Psychology Press.

Dewey, J. (1910). How we think. Boston, MA: D.C. Heath \& Co. https://doi.org/10.1037/10903-000

Dewey, J. (1938). Logic: The theory of inquiry. New York, NY: Henry Holt and Company. 
Collaborative, Interdisciplinary Reasoning

Dotson, K. (2011). Tracking epistemic violence, tracking practices of silencing. Hypatia, 26(2), 236-257. https://doi.org/10.1111/j.1527-2001.2011.01177.x

Dotson, K. (2012). A cautionary tale: On limiting epistemic oppression. Frontiers: a Journal of Women Studies, 33(1), 24. https://doi.org/10.5250/fronjwomestud.33.1.0024

Dotson, K. (2014). Conceptualizing epistemic oppression. Social Epistemology, 28(2), 115-138. https://doi.org/10.1080/02691728.2013.782585

Douglas, H. (2009). Science, policy, and the value-free ideal. Pittsburgh, PA: University of Pittsburgh Press. https://doi.org/10.2307/j.ctt6wrc78

Dreyfuss, S. (2011). Something essential about interdisciplinary thinking. Issues in Integrative Studies, 29, 67-83.

Eigenbrode, S. D., O’Rourke, M., Wulfhorst, J. D., Althoff, D. M., Goldberg, C. S., Merrill, K.,..Bosque-Pérez, N. A. (2007). Employing philosophical dialogue in collaborative science. BioScience, 57(1), 55-64. https://doi.org/10.1641/B570109

Elliott, K. C. (2017). A tapestry of values. New York, NY: Oxford University Press. https://doi.org/10.1093/acprof:oso/9780190260804.001.0001

Ferkany, M., \& Whyte, K. P. (2011). The importance of participatory virtues in the future of environmental education. Journal of Agricultural and Environmental Etbics, 25(3), 419-434. https://doi.org/10.1007/s10806$\underline{011-9312-8}$

Fricker, M. (2007). Epistemic injustice. Oxford, UK: Oxford University Press. https://doi.org/10.1093/acprof:oso/9780198237907.001.0001

Frodeman, R., Klein, J. T., \& Mitcham, C. (Eds.). (2010). The Oxford handbook of interdisciplinarity. New York, NY: Oxford University Press.

Frodeman, R., Klein, J. T., \& Pacheco, R. C. S. (Eds.). (2017). The Oxford handbook of interdisciplinarity (2 ${ }^{\text {nd }}$ ed.). Oxford: Oxford University Press. https://doi.org/10.1093/oxfordhb/9780198733522.001.0001

Habermas, J. (1985). The theory of communicative action: Volume I. (T. McCarthy, Trans.). Boston, MA: Beacon Press.

Hagstrom, W. O. (1964). Traditional and modern forms of scientific teamwork. Administrative Science Quarterly, 9(3), 241. https://doi.org/10.2307/2391440

Holbrook, J. B. (2013). What is interdisciplinary communication? Reflections on the very idea of disciplinary integration. Synthese, 190(11), 1865-1879. https://doi.org/10.1007/s11229-012-0179-7

Jeffrey, P. (2003). Smoothing the waters. Social Studies of Science, 33(4), 539-562. https://doi.org/10.1177/0306312703334003

Juthe, A. (2015). Analogical argument schemes and complex argument structure. Informal Logic, 35(3), 378-445. https://doi.org/10.22329/il.v35i3.4211

Kelly, J. S. (1996). Wide and narrow interdisciplinarity. The Journal of General Education, 45(2), 95-113. http://doi.org/10.2307/27797294

Klein, J. T. (1996). Crossing boundaries: Knowledge, disciplinarities, and interdisciplinarities. Charlottesville, VA: University of Virginia Press.

Klein, J. T. (2014a). Communication and collaboration in interdisciplinary research. In M. O'Rourke, S. Crowley, S. D. Eigenbrode, \& J. D. Wulfhorst (Eds.), Enhancing communication \& collaboration in interdisciplinary research. Thousand Oaks: SAGE Publications. https://doi.org/10.4135/9781483352947.n2

Klein, J. T. (2014b). Discourses of transdisciplinarity: Looking back to the future. Futures, 63, 68-74. https://doi.org/10.1016/i.futures.2014.08.008

Lariviere, V., \& Gingras, Y. (2014). Measuring interdisciplinarity. In B. Cronin \& C. R. Sugimoto (Eds.), Beyond bibliometrics: Harnessing multidimensional indicators of scholarly impact (pp. 187-200). MIT Press: Cambridge, MA.

Leedy, P. D., \& Ormrod, J. E. (2005). Practical researcb: Planning and design. Upper Saddle River, NJ: Pearson. 
Lewis, J. M., Ross, S., \& Holden, T. (2012). The how and why of academic collaboration: Disciplinary differences and policy implications. Higher Education, 64(5), 693-708. https://doi.org/10.1007/s10734-012-9521$\underline{8}$

Lincoln, Y. S., \& Guba, E. G. (1985). Naturalistic inquiry. Thousand Oaks, CA: SAGE Publications. https://doi.org/10.1016/0147-1767(85)90062-8

Mohr, J. W. (1998). Measuring meaning structures. Annual Review of Sociology, 24, 345-370. https://doi.org/10.1146/annurev.soc.24.1.345

National Institutes of Health National Cancer Institute. (n.d.). Team Science Toolkit. Retrieved May 23, 2015, from https://www.teamsciencetoolkit.cancer.gov/Public/Home.aspx

National Research Council. (2005). Facilitating interdisciplinary research. Washington, D.C.: National Academies Press.

National Research Council. (2015). Enhancing the effectiveness of team science. (N. J. Cooke \& M. L. Hilton, Eds.) (pp. 1-256). Washington, D.C.: National Academies Press. https://doi.org/10.17226/19007

Nikitina, S. (2005). Pathways of interdisciplinary cognition. Cognition and Instruction, 23(3), 389-425. https://doi.org/10.1207/s1532690xci2303 3

O’Rourke, M., \& Crowley, S. J. (2013). Philosophical intervention and cross-disciplinary science: The story of the Toolbox Project. Synthese, 190(11), 1937-1954. https://doi.org/10.1007/s11229-012-0175-y

O'Rourke, M., Crowley, S., \& Gonnerman, C. (2016). On the nature of cross-disciplinary integration: A philosophical framework. Studies in History and Pbilosophy of Science Part C: Studies in History and Philosopby of Biological and Biomedical Sciences. https://doi.org/10.1016/j.shpsc.2015.10.003

Ortega, M. (2006). Being lovingly, knowingly ignorant: White feminism and women of color. Hypatia: A Journal of Feminist Philosophy, 21(3), 56-74. https://doi.org/10.2979/HYP.2006.21.3.56

Piso, Z., Sertler, E., Malavisi, A., Marable, K., Jensen, E., Gonnerman, C., \& O’Rourke, M. (2016). The production and reinforcement of ignorance in collaborative interdisciplinary research. Social Epistemology, 30(5-6), 643-664. https://doi.org/10.1080/02691728.2016.1213328

Plato. (1997). Theaetatus. In J. M. Cooper \& D. S. Hutchinson (Eds.), M. J. Levitt \& M. Burnyeat (Trans.), Plato Complete Works (pp. 157-234). Hackett Publishing Company: Indianapolis, IN. (Original work published about 369 BCE.)

Porter, A. L., \& Rafols, I. (2009). Is science becoming more interdisciplinary? Measuring and mapping six research fields over time. Scientometrics, 81(3), 719-745. https://doi.org/10.1007/s11192-008-2197-2

Reed, M. S. (2008). Stakeholder participation for environmental management: A literature review. Biological Conservation, 141(10), 2417-2431. https://doi.org/10.1016/j.biocon.2008.07.014

Repko, A. F., Szostak, R., \& Buchberger, M. P. (2016). Introduction to interdisciplinary studies. Thousand Oaks, CA: SAGE Publications.

Rittel, H., \& Webber, M. M. (1973). Dilemmas in a general theory of planning. Policy Sciences, 4, 155-169. https://doi.org/10.1007/BF01405730

Salazar, M. R., Lant, T. K., Fiore, S. M., \& Salas, E. (2012). Facilitating innovation in diverse science teams through integrative capacity. Small Group Research, 43(5), 527-558. https://doi.org/10.1177/1046496412453622

Sandvik, M. (1997). Reconstructing interactive argumentative discourse. Argumentation, 11(4), 419-434. https://doi.org/10.1023/A:1007799305146

Scriven, M. (1976). Reasoning. New York, NY: McGraw-Hill Book Company.

Suthers, D. D., Lund, K., Rosé, C. P., Teplovs, C., \& Law, N. (2013). Productive multivocality in the analysis of group interactions. Boston, MA: Springer Science \& Business Media. https://doi.org/10.1007/978-1-4614-8960-3

Tuana, N. (2006). The speculum of ignorance: The women's health movement and epistemologies of ignorance. Hypatia, 21(3), 1-19. https://doi.org/10.1111/j.1527-2001.2006.tb01110.x 
van Eemeren, F. H., Garssen, B., Krabbe, E. C. W., Henkemans, A. F. S., Verheij, B., \& Wagemans, J. H. M. (2014a). The pragma-dialectical theory of argumentation. In Handbook of argumentation theory (pp. 301-372). Dordrecht: Springer Netherlands. https://doi.org/10.1007/978-90-481-9473-5 10

van Eemeren, F. H., Garssen, B., Krabbe, E. C. W., Snoeck Henkemans, A. F., Verheij, B., \& Wagemans, J. H. M. (2014b). Handbook of argumentation theory. Dordrecht: Springer Netherlands. https://doi.org/10.1007/978-90-481-9473-5

Van Noorden, R. (2015). Interdisciplinary research by the numbers. Nature, 525(7569), 306-307. https://doi.org/10.1038/525306a

Walton, D., Reed, C., \& Macagno, F. (2008). Argumentation schemes. Cambridge, UK: Cambridge University Press. https://doi.org/10.1017/CBO9780511802034

Wasserstein, R. L., \& Lazar, N. A. (2016). The ASA's statement on p-values: context, process, and purpose. The American Statistician, 70(2), 129-133. https://doi.org/10.1080/00031305.2016.1154108

Winsberg, E., Huebner, B., \& Kukla, R. (2014). Accountability and values in radically collaborative research. Studies in History and Philosophy of Science Part A, 46, 16-23. https://doi.org/10.1016/j.shpsa.2013.11.007

Wright, L. (1995). Argument and deliberation: A plea for understanding. The Journal of Philosophy, 92(11), 565585. https://doi.org/10.2307/2941088

Wright, L. (2001). Justification, discovery, reason and argument. Argumentation, 15(1), 97-104. https://doi.org/10.1023/A:1007800732356 


\section{APPENDIX}

\begin{tabular}{|c|c|c|c|c|c|}
\hline Full Speaking Turn & Contribution & Speaker & $\begin{array}{l}\text { Disciplinary } \\
\text { Perspective } \\
\text { Used }\end{array}$ & $\begin{array}{l}\text { Word } \\
\text { Count }\end{array}$ & $\begin{array}{l}\text { Premise } \\
\text { Contributed } \\
\text { To }\end{array}$ \\
\hline $\begin{array}{l}\text { 10:56 } 64 \text { SOCIOLOGIST: Well one of the } \\
\text { things I found working with many of the peo- } \\
\text { ple in the room is a term I'm still trying to } \\
\text { wrap my mind around, that I don't think we all } \\
\text { use the same way is the word modeling. }\end{array}$ & $\begin{array}{l}\text { Well one of the things I found working with } \\
\text { many of the people in the room is a term I'm } \\
\text { still trying to wrap my mind around that I don't } \\
\text { think we all use the same way is the word } \\
\text { modeling. }\end{array}$ & Sociologist & Sociology & 41 & P1 \\
\hline 65 P?: Yeah, that's one that.. & & & & 0 & \\
\hline $\begin{array}{l}\text { 66 SOCIOLOGIST: [cont'] We actually con- } \\
\text { fronted this one when we tried to write our } \\
\text { grant, we came to a heavy place that allowed us } \\
\text { to write the grant. [laughter] And it was actually } \\
\text { trying to engage the fact that modeling can } \\
\text { mean such different things to different fields. } \\
\text { And in engineering particularly I've come to } \\
\text { appreciate as a view... And until I got going on } \\
\text { our little bear project five years ago, to me } \\
\text { modeling - we model in the social sciences - } \\
\text { some of us do --is basically an exercise of de- } \\
\text { veloping some theoretical models and testing } \\
\text { them against the world and seeing how well } \\
\text { that model fits. And so we specify the model } \\
\text { that fits, as certain relationships among things } \\
\text { we can measure, and then we go and do a fairly } \\
\text { standardized set of mathematical type things } \\
\text { that say, ok that is, that explains this much of } \\
\text { what we were trying to explain, this well or } \\
\text { with this much degree of confidence. And then } \\
\text { you might go back to the drawing board and } \\
\text { re-specify and tweak and try to figure out how } \\
\text { to make your model fit those data better. }\end{array}$ & $\begin{array}{l}\text { We actually confronted this one when we tried } \\
\text { to write our grant }\end{array}$ & Sociologist & Sociology & 12 & P1 \\
\hline
\end{tabular}




\begin{tabular}{|c|c|c|c|c|c|}
\hline Full Speaking Turn & Contribution & Speaker & $\begin{array}{l}\text { Disciplinary } \\
\text { Perspective } \\
\text { Used }\end{array}$ & $\begin{array}{l}\text { Word } \\
\text { Count }\end{array}$ & $\begin{array}{l}\text { Premise } \\
\text { Contributed } \\
\text { To }\end{array}$ \\
\hline & $\begin{array}{l}\text { to me modeling - we model in the social sci- } \\
\text { ences - some of us do --is basically an exercise } \\
\text { of developing some theoretical models and } \\
\text { testing them against the world and seeing how } \\
\text { well that model fits. And so we specify the } \\
\text { model that fits, as certain relationships among } \\
\text { things we can measure, and then we go and do } \\
\text { a fairly standardized set of mathematical type } \\
\text { things that say, ok that is, that explains this } \\
\text { much of what we were trying to explain, this } \\
\text { well or with this much degree of confidence. } \\
\text { And then you might go back to the drawing } \\
\text { board and re-specify and tweak and try to fig- } \\
\text { ure out how to make your model fit those data } \\
\text { better. }\end{array}$ & Sociologist & Sociology & 120 & P2 \\
\hline 67 P?: [overlap] $\mathrm{mm} \mathrm{hmm}$ & & & & 0 & \\
\hline $\begin{array}{l}68 \text { SOCIOLOGIST: [cont'] Um, but you're } \\
\text { actually inferring sort of this significance of } \\
\text { relationships and so. }\end{array}$ & $\begin{array}{l}\text { but you're actually inferring sort of this signifi- } \\
\text { cance of relationships and so. }\end{array}$ & Sociologist & Sociology & 12 & P2 \\
\hline $\begin{array}{l}69 \text { HYDROLOGIST: [overlap] Well you just } \\
\text { described what we do. }\end{array}$ & Well you just described what we do. & Hydrologist & Hydrology & 7 & P2 \\
\hline $\begin{array}{l}70 \text { SOCIOLOGIST: [cont'] So I thought it } \\
\text { would be part of our project to explain, you } \\
\text { know variability in water quality, that we would } \\
\text { get all this raw data in water quality variability } \\
\text { and we would try to explain it using behavioral } \\
\text { variability and so forth at these various scales. } \\
\text { And what I found was we weren't actually do- } \\
\text { ing that. What we were doing was we were } \\
\text { simulating rigid models and calibrating to }\end{array}$ & $\begin{array}{l}\text { So I thought it would be part of our project to } \\
\text { explain, you know variability in water quality, } \\
\text { that we would get all this raw data in water } \\
\text { quality variability and we would try to explain it } \\
\text { using behavioral variability and so forth at } \\
\text { these various scales. And what I found was we } \\
\text { weren't actually doing that. What we were do- } \\
\text { ing was we were simulating rigid models and } \\
\text { calibrating to measured outcomes and there }\end{array}$ & Sociologist & Sociology & 120 & P4 \\
\hline
\end{tabular}




\begin{tabular}{|c|c|c|c|c|c|}
\hline Full Speaking Turn & Contribution & Speaker & $\begin{array}{l}\text { Disciplinary } \\
\text { Perspective } \\
\text { Used }\end{array}$ & $\begin{array}{l}\text { Word } \\
\text { Count }\end{array}$ & $\begin{array}{l}\text { Premise } \\
\text { Contributed } \\
\text { To }\end{array}$ \\
\hline \multirow[t]{2}{*}{$\begin{array}{l}\text { measured outcomes and there was, it kind of } \\
\text { works or it doesn't work. There wasn't the } \\
\text { same kind of process as I was, it's different in } \\
\text { some fundamental way. I'm still trying to un- } \\
\text { derstand what that difference is because I feel } \\
\text { like we're going to have to figure this out. }\end{array}$} & $\begin{array}{l}\text { was, it kind of works or it doesn't work. There } \\
\text { wasn't the same kind of process as I was, it's } \\
\text { different in some fundamental way. I'm still } \\
\text { trying to understand what that difference is } \\
\text { because I feel like we're going to have to figure } \\
\text { this out. }\end{array}$ & & & & \\
\hline & $\begin{array}{l}\text { So I thought it would be part of our project to } \\
\text { explain, you know variability in water quality, } \\
\text { that we would get all this raw data in water } \\
\text { quality variability and we would try to explain it } \\
\text { using behavioral variability and so forth at } \\
\text { these various scales. And what I found was we } \\
\text { weren't actually doing that. What we were do- } \\
\text { ing was we were simulating rigid models and } \\
\text { calibrating to measured outcomes and there } \\
\text { was, it kind of works or it doesn't work. There } \\
\text { wasn't the same kind of process as I was, it's } \\
\text { different in some fundamental way. I'm still } \\
\text { trying to understand what that difference is } \\
\text { because I feel like we're going to have to figure } \\
\text { this out. }\end{array}$ & Sociologist & Hydrology & 120 & P3 \\
\hline 71 P?: yeah & & & & 0 & \\
\hline $\begin{array}{l}72 \text { ENGINEER: [overlap] We were talking } \\
\text { about this is morning, [name], and I think one } \\
\text { aspect of it is, there's like, think about it as a } \\
\text { box. There's inputs, and there's outputs. One } \\
\text { type of model is trying to correlate those and } \\
\text { show how inputs match with the outputs just } \\
\text { however mathematically or statistical descrip- } \\
\text { tion. Then other type is processes. Trying to } \\
\text { explain how you start here and where you go }\end{array}$ & $\begin{array}{l}\text { We were talking about this this morning, } \\
\text { [name], and I think one aspect of it is, there's } \\
\text { like, think about it as a box. There's inputs, and } \\
\text { there's outputs. One type of model is trying to } \\
\text { correlate those and show how inputs match } \\
\text { with the outputs just however mathematically } \\
\text { or statistical description. Then other type is } \\
\text { processes. Trying to explain how you start here } \\
\text { and where you go next, and where you go next, }\end{array}$ & Engineer & Engineering & 100 & P5 \\
\hline
\end{tabular}




\begin{tabular}{|c|c|c|c|c|c|}
\hline Full Speaking Turn & Contribution & Speaker & $\begin{array}{l}\text { Disciplinary } \\
\text { Perspective } \\
\text { Used }\end{array}$ & $\begin{array}{l}\text { Word } \\
\text { Count }\end{array}$ & $\begin{array}{l}\text { Premise } \\
\text { Contributed } \\
\text { To }\end{array}$ \\
\hline $\begin{array}{l}\text { next, and where you go next, and where you go } \\
\text { next, and where you go next, and where you go } \\
\text { next. And then ultimately what comes out that } \\
\text { you can measure or see. }\end{array}$ & $\begin{array}{l}\text { and where you go next, and where you go next, } \\
\text { and where you go next. And then ultimately } \\
\text { what comes out that you can measure or see. }\end{array}$ & & & & \\
\hline 73 P?: [overlap] $\mathrm{mm} \mathrm{hmm}$ & & & & 0 & \\
\hline $\begin{array}{l}74 \text { ENGINEER: [cont'] And there's I think } \\
\text { probably other aspects of the problem that do } \\
\text { that too, but that seemed to, that resonates, } \\
\text { that definitely resonates with me. }\end{array}$ & $\begin{array}{l}\text { And there's I think probably other aspects of } \\
\text { the problem that do that too, but that seemed } \\
\text { to, that resonates, that definitely resonates with } \\
\text { me. }\end{array}$ & Engineer & Engineering & 25 & P5 \\
\hline $\begin{array}{l}75 \text { HYDROLOGIST: [overlap] So I think } \\
\text { maybe one of the key differences of that } \\
\text { whole, you know you get all these data and } \\
\text { then you calibrate you know the model to } \\
\text { match what happens with the data or what you } \\
\text { see and it seems like you're kind of like you're } \\
\text { just tuning things to just to make it all work. }\end{array}$ & $\begin{array}{l}\text { So I think maybe one of the key differences of } \\
\text { that whole, you know you get all these data and } \\
\text { then you calibrate you know the model to } \\
\text { match what happens with the data or what you } \\
\text { see and it feels like you're kind of like you're } \\
\text { just tuning things to just to make it all work. }\end{array}$ & Hydrologist & Hydrology & 57 & P3 \\
\hline $\begin{array}{l}76 \text { SOCIOLOGIST: [overlap] Just like turning } \\
\text { knobs. }\end{array}$ & Just like turning knobs. & Sociologist & Hydrology & 4 & P3 \\
\hline $\begin{array}{l}77 \text { HYDROLOGIST: Yeah, but in reality } \\
\text { there's very fundamental concepts or processes } \\
\text { that are represented through physics, whatever, } \\
\text { that we have representations in there and then } \\
\text { those parameters are the question marks.[BL1] } \\
\text { So you guys maybe are more empirically based } \\
\text { and you're trying to, your conceptual } \\
\text { knowledge is trying to get put together some- } \\
\text { how. We have some fundamental processes we } \\
\text { know occur, so we have to figure out whether } \\
\text { or not we're missing some. }\end{array}$ & $\begin{array}{l}\text { Yeah, but in reality there's very fundamental } \\
\text { concepts or processes that are represented } \\
\text { through physics, whatever, that we have repre- } \\
\text { sentations in there and then those parameters } \\
\text { are the question marks }\end{array}$ & Hydrologist & Hydrology & 30 & P3 \\
\hline
\end{tabular}




\begin{tabular}{|c|c|c|c|c|c|}
\hline Full Speaking Turn & Contribution & Speaker & $\begin{array}{l}\text { Disciplinary } \\
\text { Perspective } \\
\text { Used }\end{array}$ & $\begin{array}{l}\text { Word } \\
\text { Count }\end{array}$ & $\begin{array}{l}\text { Premise } \\
\text { Contributed } \\
\text { To }\end{array}$ \\
\hline & $\begin{array}{l}\text { So you guys maybe are more empirically based } \\
\text { and you're trying to, you conceptual knowledge } \\
\text { is trying to get put together somehow. }\end{array}$ & Hydrologist & Sociology & 22 & P4 \\
\hline & $\begin{array}{l}\text { We have some fundamental processes we } \\
\text { know occur, so we have to figure out whether } \\
\text { or not we're missing some. }\end{array}$ & Hydrologist & Hydrology & 20 & P3 \\
\hline $\begin{array}{l}\text { 14:23 } 78 \text { SOCIOLOGIST [interrupting]: this } \\
\text { becomes a really big issue in building human } \\
\text { dimensions in, because we're not usually able -- } \\
\text { and we're always asked, I was asked just today - } \\
\text { - to serve up a sort of direct process relation- } \\
\text { ship. So "if you do this, this is what happens," } \\
\text { or "this is how people will behave," because } \\
\text { it's like we need to know that to be able to use } \\
\text { this in this framework. We understand sort of } \\
\text { how water moves in the soil in this really com- } \\
\text { plicated way with all these equations, and now } \\
\text { we need to understand if the humans are going } \\
\text { to be a part of that process model, how do we } \\
\text { write the code to represent [cut off by laughter] }\end{array}$ & $\begin{array}{l}\text { this becomes a really big issue in building hu- } \\
\text { man dimensions in, because we're not usually } \\
\text { able -- and we're always asked, I was asked just } \\
\text { today -- to serve up a sort of direct process } \\
\text { relationship. So "if you do this, this is what } \\
\text { happens," or "this is how people will behave," } \\
\text { because it's like we need to know that to be } \\
\text { able to use this in this framework. We under- } \\
\text { stand sort of how water moves in the soil in } \\
\text { this really complicated way with all these equa- } \\
\text { tions, and now we need to understand if the } \\
\text { humans are going to be a part of that process } \\
\text { model, how do we write the code to represent }\end{array}$ & Sociologist & Sociology & 115 & P3 \\
\hline $\begin{array}{l}\text { 15:00 } 79 \text { ENGINEER: [overlap] Well you can } \\
\text { do it two ways though right? Because you } \\
\text { could just, say the hydro-economic stuff that I } \\
\text { presented last time was just embedding that, } \\
\text { that economic understanding, the empirics of } \\
\text { that into that process without really under- } \\
\text { standing in detail what's driving that behavior, } \\
\text { or you can try and, you can try and go with that } \\
\text { some more too. [long pause] It seems like } \\
\text { though, that as I'm thinking about it, and I'm } \\
\text { curious to hear what everyone else's thoughts }\end{array}$ & $\begin{array}{l}\text { Well you can do it two ways though right? Be- } \\
\text { cause you could just, say the hydro-economic } \\
\text { stuff that I presented last time was just embed- } \\
\text { ding that, that economic understanding, the } \\
\text { empirics of that into that process without really } \\
\text { understanding in detail what's driving that be- } \\
\text { havior }\end{array}$ & Engineer & Engineering & 45 & P3 \\
\hline
\end{tabular}




\begin{tabular}{|c|c|c|c|c|c|}
\hline Full Speaking Turn & Contribution & Speaker & $\begin{array}{l}\text { Disciplinary } \\
\text { Perspective } \\
\text { Used }\end{array}$ & $\begin{array}{l}\text { Word } \\
\text { Count }\end{array}$ & $\begin{array}{l}\text { Premise } \\
\text { Contributed } \\
\text { To }\end{array}$ \\
\hline \multicolumn{6}{|l|}{$\begin{array}{l}\text { are on this, is that if you have an empirically } \\
\text { based model, that's a method of calibration in a } \\
\text { sense. }\end{array}$} \\
\hline & $\begin{array}{l}\text { or you can try and, you can try and go with that } \\
\text { some more too. }\end{array}$ & Engineer & Engineering & 15 & P3 \\
\hline & $\begin{array}{l}\text { It seems like though, that as I'm thinking about } \\
\text { it, and I'm curious to hear what everyone else's } \\
\text { thoughts are on this, is that if you have an em- } \\
\text { pirically based model, that's a method of cali- } \\
\text { bration in a sense. }\end{array}$ & Engineer & Engineering & 39 & P2 \\
\hline 80 HYDROLOGIST: Right. & & & & 0 & \\
\hline $\begin{array}{l}81 \text { SOCIOLOGIST: I actually calibrated a } \\
\text { model just the other day so I could tell you if } \\
\text { that's true or not. }\end{array}$ & $\begin{array}{l}\text { I actually calibrated a model just the other day } \\
\text { so I could tell you if that's true or not. }\end{array}$ & Sociologist & Sociology & 19 & P4 \\
\hline 82 HYDROLOGIST: Right. & & Hydrologist & & 0 & \\
\hline [laughter] & & & & 0 & \\
\hline $\begin{array}{l}83 \text { SOCIOLOGIST: I'd like to sit down when } \\
\text { you're calibrating some models, or I'd be will- } \\
\text { ing to take name's class }\end{array}$ & $\begin{array}{l}\text { I'd like to sit down when you're calibrating } \\
\text { some models, or I'd be willing to take name's } \\
\text { class }\end{array}$ & Sociologist & Hydrology & 18 & P3 \\
\hline 84 P?: [overlap] $\mathrm{mm} \mathrm{hmm}$ & & & & 0 & \\
\hline $\begin{array}{l}\text { 16:00 } 85 \text { SOCIOLOGIST: [cont'] so I can } \\
\text { tweak some knobs and find out, ok, "now I } \\
\text { actually understand what you mean when you } \\
\text { say that," um and whether it's really the same } \\
\text { or different from what I'm used to doing, } \\
\text { training my students to do. When I do just my }\end{array}$ & $\begin{array}{l}\text { so I can tweak some knobs and find out, ok, } \\
\text { "now I actually understand what you mean } \\
\text { when you say that," um and whether it's really } \\
\text { the same or different from what I'm used to } \\
\text { doing, training my students to do. }\end{array}$ & Sociologist & Hydrology & 41 & P3 \\
\hline
\end{tabular}




\begin{tabular}{|c|c|c|c|c|c|}
\hline Full Speaking Turn & Contribution & Speaker & $\begin{array}{l}\text { Disciplinary } \\
\text { Perspective } \\
\text { Used }\end{array}$ & $\begin{array}{l}\text { Word } \\
\text { Count }\end{array}$ & $\begin{array}{l}\text { Premise } \\
\text { Contributed } \\
\text { To }\end{array}$ \\
\hline \multicolumn{6}{|l|}{$\begin{array}{l}\text { sociology it's over here, and that's what I do. } \\
\text { And when I work on these teams I've not al- } \\
\text { ways been able to bring that into the conversa- } \\
\text { tion, especially in modeling part. }\end{array}$} \\
\hline & $\begin{array}{l}\text { When I do just my sociology it's over here, and } \\
\text { that's what I do. And when I work on these } \\
\text { teams I've not always been able to bring that } \\
\text { into the conversation, especially in modeling } \\
\text { part. }\end{array}$ & Sociologist & Sociology & 36 & P4 \\
\hline 86 P?: [overlap] $\mathrm{mm}$ hmm & & & & 0 & \\
\hline $\begin{array}{l}87 \text { SOCIOLOGIST: [cont'] The modeling part } \\
\text { is always sort of what you guys are used to do- } \\
\text { ing and I'm trying to figure out, how to insert } \\
\text { important things that I understand into that, } \\
\text { but it doesn't strike me as the same exercise. } \\
\text { Or maybe it's more so the same and I don't } \\
\text { understand. }\end{array}$ & $\begin{array}{l}\text { The modeling part is always sort of what you } \\
\text { guys are used to doing and I'm trying to figure } \\
\text { out, how to insert important things that I un- } \\
\text { derstand into that, but it doesn't strike me as } \\
\text { the same exercise. Or maybe it's more so the } \\
\text { same and I don't understand. }\end{array}$ & Sociologist & Hydrology & 50 & P3 \\
\hline $\begin{array}{l}88 \text { ENGINEER: I think it could be both. } \\
\text { Meaning there's similarities, and there's obvi- } \\
\text { ously different contexts, [unclear] so there's the } \\
\text { opportunity for difference as well. }\end{array}$ & $\begin{array}{l}\text { I think it could be both. Meaning there's simi- } \\
\text { larities, and there's obviously different con- } \\
\text { texts, [unclear] so there's the opportunity for } \\
\text { difference as well. }\end{array}$ & Engineer & Engineering & 23 & P5 \\
\hline $\begin{array}{l}89 \text { HYDROLOGIST: But what you described } \\
\text { is what you do for a model, you're approach to } \\
\text { modeling? I'm just sitting here going, hmmm } \\
\text { yep. }\end{array}$ & $\begin{array}{l}\text { But what you described is what you do for a } \\
\text { model anyway, you're approach to modeling? } \\
\text { I'm just sitting here going, hmmm yep. }\end{array}$ & Hydrologist & Hydrology & 23 & $\mathrm{P} 2$ \\
\hline 90 P?: [overlap] $\mathrm{mm}$ hmm & & & & 0 & \\
\hline $\begin{array}{l}91 \text { HYDROLOGIST: [overlap] cont Sounds } \\
\text { like what we do. So it's kind of interesting that }\end{array}$ & Sounds like what we do. & Hydrologist & Hydrology & 5 & P2 \\
\hline
\end{tabular}




\begin{tabular}{|c|c|c|c|c|c|}
\hline Full Speaking Turn & Contribution & Speaker & $\begin{array}{l}\text { Disciplinary } \\
\text { Perspective } \\
\text { Used }\end{array}$ & $\begin{array}{l}\text { Word } \\
\text { Count }\end{array}$ & $\begin{array}{l}\text { Premise } \\
\text { Contributed } \\
\text { To }\end{array}$ \\
\hline \multicolumn{6}{|l|}{$\begin{array}{l}\text { we can do this and sometimes diverge at the } \\
\text { end, at least in terms of understanding each } \\
\text { other. }\end{array}$} \\
\hline & $\begin{array}{l}\text { So it's kind of interesting that we can do this } \\
\text { and sometimes diverge at the end, at least in } \\
\text { terms of understanding each other. }\end{array}$ & Hydrologist & Engineering & 24 & P5 \\
\hline $\begin{array}{l}92 \text { SOCIOLOGIST: We just don't start with } \\
\text { any process relationships, those are all to be } \\
\text { discovered. }\end{array}$ & $\begin{array}{l}\text { We just don't start with any process relation- } \\
\text { ships, those are all to be discovered. }\end{array}$ & Sociologist & Sociology & 14 & P4 \\
\hline 93 HYDROLOGIST: [overlap] Right. & & & & 0 & \\
\hline $\begin{array}{l}94 \text { SOCIOLOGIST: [cont'] And tested, so we } \\
\text { don't understand anything at the outset that we } \\
\text { can put into that model that says this will al- } \\
\text { ways do that or these will be the fixed relation- } \\
\text { ships. }\end{array}$ & $\begin{array}{l}\text { And tested, so we don't understand anything at } \\
\text { the outset that we can put into that model that } \\
\text { says this will always do that or these will be the } \\
\text { fixed relationships. }\end{array}$ & Sociologist & Sociology & 31 & P4 \\
\hline 95 ENGINEER: [overlap] $\mathrm{mm} \mathrm{hm.}$ & & & & 0 & \\
\hline HYDROLOGIST: Right & & & & 0 & \\
\hline $\begin{array}{l}96 \text { SOCIOLOGIST: [cont'] We do in fact do } \\
\text { that in the sense that we specify a model with a } \\
\text { certain structure and it defines how it could } \\
\text { work, }\end{array}$ & $\begin{array}{l}\text { We do in fact do that in the sense that we spec- } \\
\text { ify a model with a certain structure and it de- } \\
\text { fines how it could work, }\end{array}$ & Sociologist & Sociology & 25 & P4 \\
\hline 97 P?: [overlap] Right. & & & & 0 & \\
\hline $\begin{array}{l}98 \text { SOCIOLOGIST: [cont'] but people - some } \\
\text { people like me -- obsess about getting specifi- } \\
\text { cation right, }\end{array}$ & $\begin{array}{l}\text { but people - some people like me -- obsess } \\
\text { about getting specification right, }\end{array}$ & Sociologist & Sociology & 13 & P4 \\
\hline
\end{tabular}




\begin{tabular}{|c|c|c|c|c|c|}
\hline Full Speaking Turn & Contribution & Speaker & $\begin{array}{l}\text { Disciplinary } \\
\text { Perspective } \\
\text { Used }\end{array}$ & $\begin{array}{l}\text { Word } \\
\text { Count }\end{array}$ & $\begin{array}{l}\text { Premise } \\
\text { Contributed } \\
\text { To }\end{array}$ \\
\hline 99 P?: [overlap] Right. & & & & 0 & \\
\hline $\begin{array}{l}100 \text { SOCIOLOGIST: [cont'] and others don't } \\
\text { worry about it - throw a model out there. } \\
\text { Move on to the next paper. You know. Who } \\
\text { cares if your operationalization was stupid. }\end{array}$ & $\begin{array}{l}\text { and others don't worry about it - throw a } \\
\text { model out there. Move on to the next paper. } \\
\text { You know. Who cares if you're not operation- } \\
\text { alization was stupid. }\end{array}$ & Sociologist & Sociology & 28 & P4 \\
\hline 101 P?: [overlap] yeah & & & & 0 & \\
\hline $\begin{array}{l}\text { 17:43 } 102 \text { SOCIOLOGIST: [cont'] you know } \\
\text { whatever, but [unclear] }\end{array}$ & & & & 0 & \\
\hline $\begin{array}{l}103 \text { HYDROLOGIST: Hey! So maybe it's just } \\
\text { that we all come up with conceptual models } \\
\text { similarly, but it's the actual implementation of } \\
\text { it? }\end{array}$ & $\begin{array}{l}\text { Hey! So maybe it's just that we all come up } \\
\text { with conceptual models similarly, but it's the } \\
\text { actual implementation of it? }\end{array}$ & Hydrologist & Engineering & 21 & P5 \\
\hline $\begin{array}{l}104 \text { SOCIOLOGIST: Seems to be. It's yeah } \\
\text { the practice of what we actually do when say } \\
\text { we go out and model. }\end{array}$ & $\begin{array}{l}\text { Seems to be. It's yeah the practice of what we } \\
\text { actually do when say we go out and model. }\end{array}$ & Sociologist & Sociology & 19 & P5 \\
\hline
\end{tabular}




\section{BIOGRAPHY}

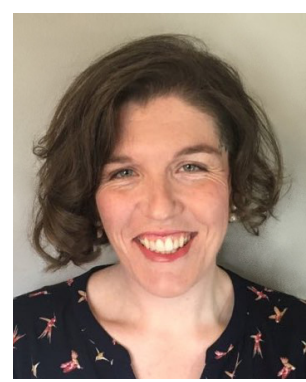

Bethany K. Laursen is an M.A. student in Philosophy and a Ph.D. student in Community Sustainability at Michigan State University. She previously received a B.S. in Biological Science with a minor in Chemistry from Biola University, and an M.S. in Environment \& Resources and Forestry from UW-Madison. After practicing as an interdisciplinary environmental scholar and educator for 10 years, she switched fields to study theories of interdisciplinarity itself. She is particularly interested in tools that enhance interdisciplinary reasoning in sustainability studies. 